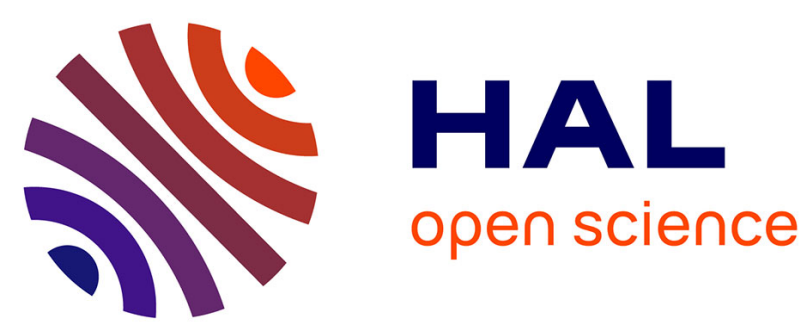

\title{
Climatology of aerosol composition (organic versus inorganic) at nonurban sites on a west-east transect across Europe
}

Casimiro Pio, Michel Legrand, Tiago Oliveira, Joana Afonso, C. Santos, Alexandre Caseiro, Paulo Fialho, Filipe Barata, Hans Puxbaum, Asunción

Sánchez-Ochoa, et al.

\section{To cite this version:}

Casimiro Pio, Michel Legrand, Tiago Oliveira, Joana Afonso, C. Santos, et al.. Climatology of aerosol composition (organic versus inorganic) at nonurban sites on a west-east transect across Europe. Journal of Geophysical Research: Atmospheres, 2007, 112 (D23S02), 1 à 15 p. 10.1029/2006JD008038 . insu-00377242

\section{HAL Id: insu-00377242 \\ https://hal-insu.archives-ouvertes.fr/insu-00377242}

Submitted on 25 Mar 2021

HAL is a multi-disciplinary open access archive for the deposit and dissemination of scientific research documents, whether they are published or not. The documents may come from teaching and research institutions in France or abroad, or from public or private research centers.
L'archive ouverte pluridisciplinaire $\mathbf{H A L}$, est destinée au dépôt et à la diffusion de documents scientifiques de niveau recherche, publiés ou non, émanant des établissements d'enseignement et de recherche français ou étrangers, des laboratoires publics ou privés. 


\title{
Climatology of aerosol composition (organic versus inorganic) at nonurban sites on a west-east transect across Europe
}

\author{
C. A. Pio, ${ }^{1}$ M. Legrand ${ }^{2}$ T. Oliveira, ${ }^{1}$ J. Afonso, ${ }^{1}$ C. Santos, ${ }^{1}$ A. Caseiro, ${ }^{1,4}$ P. Fialho, ${ }^{3}$ \\ F. Barata, ${ }^{3}$ H. Puxbaum, ${ }^{4}$ A. Sanchez-Ochoa, ${ }^{4}$ A. Kasper-Giebl, ${ }^{4}$ A. Gelencsér, ${ }^{5}$ \\ S. Preunkert, ${ }^{2}$ and M. Schock ${ }^{6}$
}

Received 15 September 2006; revised 11 December 2006; accepted 6 July 2007; published 1 September 2007.

[1] In the framework of the European CARBOSOL project (Present and Retrospective State of Organic versus Inorganic Aerosol over Europe: Implications for Climate), atmospheric aerosol was continuously sampled for 2 years at six sites along a west-east transect extending from Azores, in the mid-Atlantic Ocean, to K-Puszta (Hungary),

in central Europe. Aerosols were analyzed for ${ }^{210} \mathrm{~Pb}$, inorganic ions, elemental (EC) and organic (OC) carbon, water soluble organic carbon (WSOC), macromolecular type

(humic-like) organic substances (HULIS), $\mathrm{C}_{2}-\mathrm{C}_{5}$ diacids, cellulose, and levoglucosan.

Pooled aerosol filters were also used for the identification of different families of organic compounds by gas chromatography/mass spectrometry, GC/MS, as well as ${ }^{14} \mathrm{C}$

determinations. The data resulted in a climatological overview of the aerosol composition over Europe in the various seasons, from west to east, and from the boundary layer to the free troposphere. The paper first summarizes the characteristics of the sites and collected samples and then focuses on the aerosol mass partitioning (mass closure, inorganic versus organic, EC versus OC, water soluble versus insoluble OC), giving an insight on the sources of carbonaceous aerosol present in rural and natural background areas in Europe. It also introduces the main role of other companion papers dealing with CARBOSOL aerosol data that are also presented in this issue.

Citation: Pio, C. A., et al. (2007), Climatology of aerosol composition (organic versus inorganic) at nonurban sites on a west-east transect across Europe, J. Geophys. Res., 112, D23S02, doi:10.1029/2006JD008038.

\section{Introduction}

[2] Atmospheric aerosols influence climate directly through scattering and absorbing radiation, and indirectly by acting as condensation nuclei for clouds, with modification of the clouds optical properties and lifetime, probably resulting in a negative forcing. Furthermore, aerosols have deleterious health effects as they often contain toxins and/or carcinogens that contribute to cardiopulmonary diseases and mortality [Pope, 2000; Pöschl, 2005].

[3] Model estimates of the global cooling due to manmade aerosols suggest that anthropogenic aerosols could

\footnotetext{
${ }^{1}$ Centre for Environmental and Marine Studies and Department of Environment, University of Aveiro, Aveiro, Portugal.

${ }^{2}$ Laboratoire de Glaciologie et Géophysique de l'Environnement, Centre National de la Recherche Scientifique, Saint Martin d'Héres, France.

${ }^{3}$ Department of Agrarian Sciences, University of the Azores, Angra do Heroísmo, Portugal.

${ }^{4}$ Institute for Chemical Technologies and Analytics, Vienna University of Technology, Vienna, Austria.

${ }^{5}$ Air Chemistry Group at the Hungarian Academy of Sciences, University of Pannonia, Veszprém, Hungary.

${ }^{6}$ Institut für Umweltphysik, Universität Heidelberg, Heidelberg, Germany.

Copyright 2007 by the American Geophysical Union. 0148-0227/07/2006JD008038
}

counterbalance the warming due to growing levels of greenhouse gases by some $30 \%$, possibly up to $50-80 \%$ [Charlson et al., 1992; Penner et al., 1994; Jacobson, 2001; Bellouin et al., 2005]. Thus aerosols may have weakened the rate of the global warming during the last century [Andreae et al., 2005]. However, numerous uncertainties still exist in estimating the climatic impact of aerosols, which is thought to be larger over industrialized regions [Menon, 2004]. This is mostly because the spatial distribution of aerosols is very heterogeneous, requiring numerous investigations in time and space to serve as inputs and constraints for climate models.

[4] The most important inorganic aerosol component in terms of radiative forcing is sulfate which has well known optical properties. The sources of sulfate are rather well quantified and $\mathrm{SO}_{2}$ anthropogenic emissions are well documented, at least for the regions of interest in this study (western and central Europe) [Lefohn et al., 1999; van Aardenne et al., 2001]. The present-day spatial distribution of sulfate is documented throughout Europe at numerous low-level sites, as well as at some sites located above $1000 \mathrm{~m}$. Current evaluations of the present-day direct radiative forcing by sulfate over Europe are in self agreement, within a factor of 2, with the main uncertainties related to the assumed sulfate distribution which depends on deployed chemistry-transport schemes, the assumption on size distri- 
bution and the degree of internal or external mixing [Boucher et al., 1998]. Much larger uncertainties exist in evaluating the indirect effect [Penner et al., 1998; Lohmann et al., 2000; Menon, 2004].

[5] Although carbonaceous particles are now recognized, together with sulfate, as major components of fine aerosol [Heintzenberg, 1989; Zappoli et al., 1999], there is a large uncertainty on their sources (biogenic versus anthropogenic, primary versus secondary), their complex chemical nature and optical properties [Gelencsér, 2004]. Total carbon in atmospheric aerosol can be routinely determined. Analytical methods are able to differentiate between organic (OC, a scattering material), and elemental carbon (EC), or black carbon (BC), a light absorbing material with a graphite-type crystalline structure. Usually the term $\mathrm{BC}$ is used for measurements based purely on optical methods, while EC is associated with thermal analytical methods and the direct determination of carbon [Gelencsér, 2004]. The split between $\mathrm{OC}$ and $\mathrm{EC}$ is rather arbitrary and has been a subject of controversy for the last decades [Schmid et al., 2001]. EC lies generally in the submicron range whereas OC exhibits a wider size distribution, which remains poorly documented. The hygroscopic properties of OC and EC are not well established, although laboratory studies have suggested hydrophobic behavior for fresh particles and enhancement of hygroscopicity after contact with oxidants [Gelencsér, 2004]. Bulk OC can be divided into water soluble (WSOC) and water insoluble (WinOC) parts. The hygroscopic properties of bulk OC are widely unknown although some WSOC species like dicarboxylic acids are known to be very hygroscopic [Saxena et al., 1995].

[6] In the existing data, EC and OC are mainly separated as carbonaceous fractions, and only very recent studies started to discriminate WSOC and WinOC. On the other hand, organic speciation using recent analytical methods have failed to assign more than $15 \%$ of total carbon to individual organic compound classes such as n-alkanes, carboxylic acids, terpenoids, etc. [Alves et al., 2002; Pio et al., 2001]. It seems that failure in organic speciation results from the fact that most $\mathrm{OC}$ in aerosol is contained in oligomeric or polymeric matter. Spectroscopic data on WSOC fraction shows that its properties present large similarities to those of terrestrial or aquatic humic and fulvic acids, and recently it was demonstrated that they were made up of similar structural units [Simoneit and Mazurek, 1982]. Another important fraction was shown to consist of other biopolymers such as cellulose [Puxbaum and Tenze-Kunit, 2003]. Given that, the organic oligomers and polymers may constitute a major part of $\mathrm{OC}$, but their origins are still an open question.

[7] Until now most of the research on carbonaceous aerosol has been focused on urban areas, where traffic represents a main source of pollution, or on areas highly impacted by biomass burning. In contrast, only a few studies have investigated remote, rural or semirural environments, and most of them were restricted to short-time campaigns (see Putaud et al. [2004] for a recent review focused on Europe).

[8] This paper gives an overview of the network sampling scheme deployed to measure inorganic and carbonaceous aerosol constituents at rural and background sites in Europe, in the framework of the European CARBOSOL project
[Legrand and Puxbaum, 2007]. It focuses on major fractions of aerosol, namely the rather well-known inorganic ions, EC and $\mathrm{OC}$, and its different subfractions versus volatility, and the water soluble organic fraction. The climatology of these aerosol fractions is discussed, with backup of information from ${ }^{210} \mathrm{~Pb}$, to highlight the effect of continentality along the west to east transect, as well as the vertical mixing, particularly at mountain sites. The paper also introduces several companion papers of this issue dedicated to more specific organic species investigated in parallel during the CARBOSOL project.

\section{Sampling}

[9] Aerosol was collected at six sites along a west-east European transect of $4000 \mathrm{~km}$, extending from Azores (Portugal) in the middle of the central-north Atlantic Ocean, to K-Puszta (Hungary) in the central European plains (Figure 1). Referring to the classification given by Van Dingenen et al. [2004] for Europe, the sites can be classified into marine background (Azores), rural background (Aveiro and K-Puszta: lowland; Schauinsland: mountain), and natural continental background (Puy de Dome and Sonnblick: free troposphere in winter).

[10] At Azores (AZO) $\left(38^{\circ} 41^{\prime} \mathrm{N}, 27^{\circ} 21^{\prime} \mathrm{W}\right)$ sampling was done at top of a $50 \mathrm{~m}$ high cliff over the sea, west of the Terceira Island $\left(397 \mathrm{~km}^{2}, 60,000\right.$ inhabitants). The site area is used for cattle grazing and horticulture. The Azores are in the mid-north Atlantic Ocean, representative of background marine atmosphere, with levels frequently influenced by transport from North America and, to a lesser degree, from Europe and Africa. Aerosol was sampled by sucking air at a flow rate of $1.1 \mathrm{~m}^{3} \mathrm{~min}^{-1}$ through quartz fiber filters (Whatman QM-A, $10 \times 8$ inches). The sampler stands $2.5 \mathrm{~m}$ above the ground and was run with an Anderson PM10 inlet to remove particles larger than $10 \mu \mathrm{m}$. The filter holder had a Tisch $2.5 \mu \mathrm{m}$ impactor stage which separates particles larger and smaller than $2.5 \mu \mathrm{m}$. Only PM2.5 particles were analyzed.

[11] At Aveiro (AVE) $\left(40^{\circ} 35^{\prime} \mathrm{N}, 8^{\circ} 38^{\prime} \mathrm{W}\right)$ sampling was performed at $2.5 \mathrm{~m}$ above the ground using a system similar to the AZO one. The sampling site is located in a rural area used to grow maize in spring and summer. The site ( $47 \mathrm{~m}$ asl) is located on the west coast of Portugal, $10 \mathrm{~km}$ from the Atlantic Ocean, and $6 \mathrm{~km}$ southeast from the small town of Aveiro (50,000 inhabitants). The region is characterized by maritime pine and eucalyptus forests and small-scale agricultural fields (horticulture and maize growing).

[12] The Puy de Dôme (PDD) $\left(45^{\circ} 46^{\prime} \mathrm{N}, 2^{\circ} 57^{\prime} \mathrm{E}\right)$ site is located at the Microphysics and Chemistry station run by the Observatoire de Physique du Globe de Clermont Ferrand (OPGC) on the top of the Puy de Dome mountain $(1450 \mathrm{~m}$ asl), in central France. In winter the site is very often under free tropospheric conditions [Sellegri et al., 2003]. Details on the station can be found at http:// wwwobs.univ-bpclermont.fr/atmos/pdd/visitepuydedome/ accueil.htm. The region is characterized by intensive agriculture, cattle husbandry and forest management activities. Aerosol was sampled at a flow rate of $1.1 \mathrm{~m}^{3} \mathrm{~min}^{-1}$ on circular quartz filters (Gelman Pallflex Tissuquartz 2500QAT-UP) with $15 \mathrm{~cm}$ diameter (filter holder from 


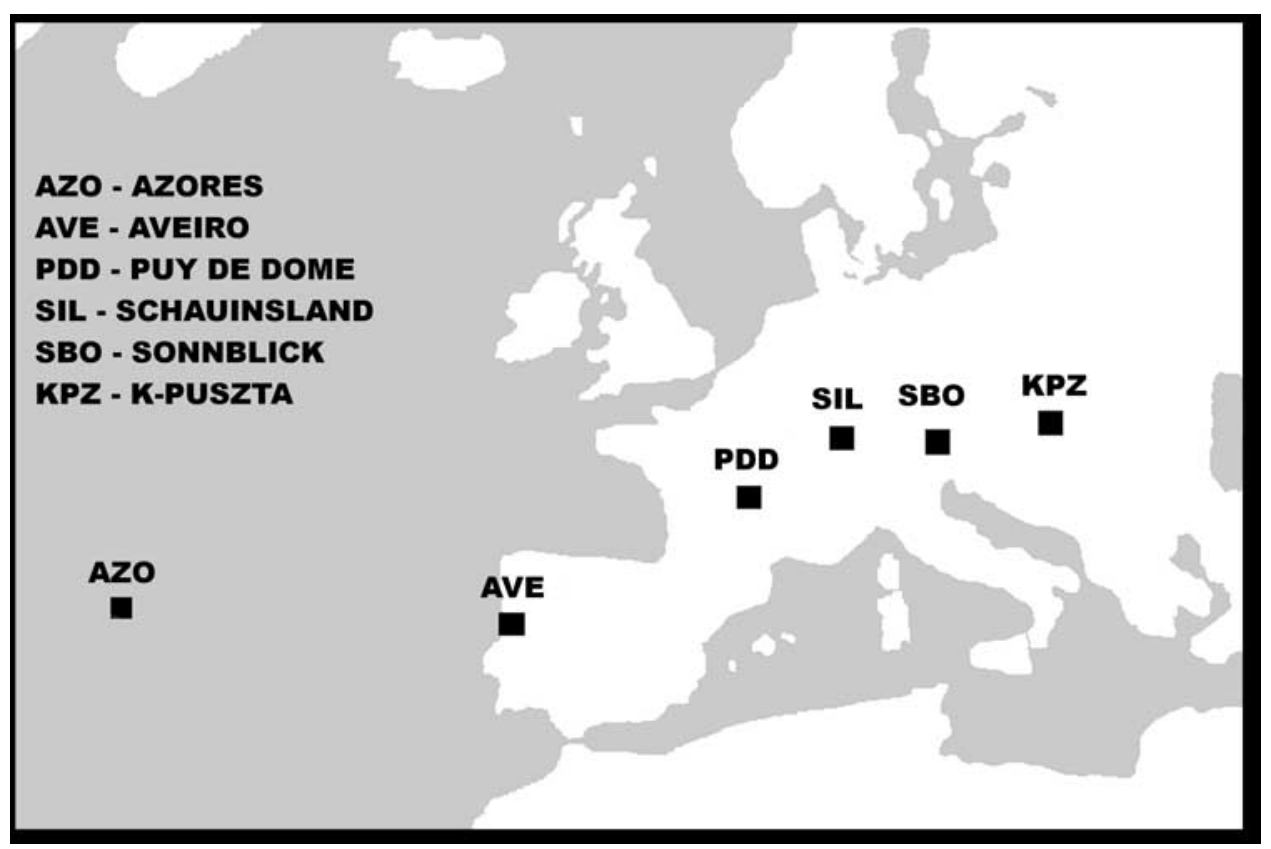

Figure 1. Location of the six CARBOSOL sites in Europe.

Digitel). The air inlet is located $6 \mathrm{~m}$ above the ground and equipped with a heated rain/snow shelter (Digitel) which has a cutoff size of $10 \mu \mathrm{m}$.

[13] The Schauinsland (SIL) $\left(47^{\circ} 55^{\prime} \mathrm{N}, 07^{\circ} 54^{\prime} \mathrm{E}\right)$ sampling site is located at the Global Atmosphere Watch (GAW) station run by the German Federal Environmental Agency (http://www.empa.ch/gaw/gawsis/reports.asp? StationID=93). The station is on a mountain ridge (1205 $\mathrm{m}$ asl) in the Black Forest (southwestern Germany). It is surrounded by coniferous forests (50\%), meadows (40\%) and some agricultural fields $(10 \%)$. The city of Freiburg is located in the Rhine valley at $12 \mathrm{~km}$ southwest from the site. The station is usually situated above the groundlevel atmospheric inversion layer of the densely populated Rhine Valley. However, during summer, strong thermal convections may transport air masses from the Rhine valley to the SIL station. Aerosol was sampled at a flow rate of $0.9 \mathrm{~m}^{3} \mathrm{~min}^{-1}$ on circular quartz filters (Gelman Pallflex Tissuquartz 2500QAT-UP) with a diameter of $15 \mathrm{~cm}$. The air inlet, similar to the PDD one, was located at $4 \mathrm{~m}$ above the ground.

[14] The Sonnblick (SBO) $\left(47^{\circ} 03^{\prime} \mathrm{N}, 12^{\circ} 57^{\prime} \mathrm{E}\right)$ site is the Sonnblick Observatory (SBO) operated by the Central Institute for Meteorology and Geodynamics. It is located on a mountain peak (3106 $\mathrm{m}$ asl) in the main ridge of the Austrian Alps and is frequently above the atmospheric mixing layer [Kasper and Puxbaum, 1998]. The observatory is supplied with electricity and has no local sources of exhaust fumes. More details on SBO can be found at http:// www.amap.no/envinet/site.cfm?SiteID=4. Atmospheric aerosol was sampled with a high-volume sampler (Digitel) at a flow rate of $0.5 \mathrm{~m}^{3} \mathrm{~min}^{-1}$ on quartz fiber (Gelman Pallflex Tissuquartz 2500QAT-UP) $15 \mathrm{~cm}$ diameter filters. The sampler is set up on the roof platform of the observatory and is equipped with a PM2.5 inlet.
[15] At K-Puszta (KPZ) $\left(46^{\circ} 58^{\prime} \mathrm{N}, 19^{\circ} 35^{\prime} \mathrm{E}\right)$ aerosols were collected at the station run by the Hungarian Meteorological Service and the University of Veszprém, as part of the GAW and EMEP (Convention on Long-range Transboundary Air Pollution) (http://www.nilu.no/projects/ccc/sitedescriptions/ hu/index.html) networks. The site is in the middle of the Hungarian Plain, $60 \mathrm{~km}$ southeast from Budapest (1.9 million inhabitants). The largest nearby town (Kecskemét, 110,000 inhabitants) is located $15 \mathrm{~km}$ southeast from the station. The sampling site is surrounded by forests $(62 \%$ coniferous trees) interspersed with clearings. Aerosol was sampled at a flow rate of $0.6 \mathrm{~m}^{3} \mathrm{~min}^{-1}$ (Sierra-Andersen impactor) on quartz fiber filters (Whatman QM-A) of $20 \times$ $25 \mathrm{~cm}$ size. The sampler is located at $7 \mathrm{~m}$ above ground and was configured to remove particles larger than $2 \mu \mathrm{m}$.

[16] As above mentioned, in contrast to AZO, AVE, SBO and KPZ where a PM 2-2.5 inlet was deployed, at SIL and PDD a PM 10 inlet was used. That has to be kept in mind when comparing data related to coarse particles. Nevertheless, a size distribution study carried in different types of air masses at PDD have shown that, except during sporadic Saharan dust event, the aerosol mass (organic and inorganic) is mainly present below $3 \mu \mathrm{m}$ [Sellegri et al., 2003].

[17] Samples were collected, almost continuously, during 2 full years at each site. At AZO, AVE and KPZ, sampling was initiated beginning of July 2003. At the remaining sites sampling started in October of the same year. At AVE and SIL no weekly samples were lost. At other sites, such as AZO, several samples could not be collected properly, mainly in winter, as result of equipment breakdown associated with bad weather conditions and electricity supply failures. The 538 weekly aerosol filters collected at the six sites were analyzed for inorganic ions, EC and OC, WSOC, HULIS, $\mathrm{C}_{2}-\mathrm{C}_{5}$ dicarboxylic acids, cellulose, and levoglucosan. Except at AZO all filters were investigated for ${ }^{210} \mathrm{~Pb}$. Weekly filter samples, collected from July 2002 to 
September 2003, were pooled monthly ( 86 samples) for the identification of different class species (alkanes, aldehydes, ketones, alcohols, acids, and aromatics) by GC/MS. With the exception of AZO, 65 weekly aerosol filters collected at the 5 other sites were selected, by considering their season and ${ }^{210} \mathrm{~Pb}$ levels as related to the continentality of the sampled air mass (total of 13 single filters and 5 pooled samples) for ${ }^{14} \mathrm{C}$ determinations. Additional measurements included a few size-segregated sampling with a highvolume impactor at AVE and KPZ.

[18] To collect enough material for conducting all analysis, even at remote oceanic and mountain sites, weekly sampling was applied to avoid problems related to detection limits of the deployed analytical methods. Because of the long sampling period, alteration of aerosol may have occurred on filters during sampling in relation to either the organic or inorganic constituents of aerosol. During the long sampling period it is probable that filtered organic particulate matter suffers chemical transformation resulting in partial oxidation of the more thermodynamically unstable organic species, as result of attack by strong oxidants, such as ozone, over the filter. This has to be taken into account in the interpretation of the results. Also condensation/volatilization processes may happen into and from the deposited particles and on reactive sites on filter quartz fibers. Therefore results for semivolatile compounds, such as low ring number PAHs (poli-aromatic hydrocarbons) and ammonium nitrate, have to be regarded with precaution.

[19] It can, however, been assumed that, during sampling, equilibrium between gas and particulate phase would govern the behavior of the filtered aerosol similarly to what happens in the atmosphere. Furthermore the large mass of particles collected would reduce potential adsorption of semivolatile organic and inorganic compounds on active sites of the quartz fibers surface, as result of their rapid saturation.

[20] To reduce contamination by organic material, quartz filters for PDD, SIL and SBO were prefired in factory, whereas for AZO, AVE and KPZ, filters were pretreated by heating in a furnace during several hours at $500-700^{\circ} \mathrm{C}$ in laboratory. After that, filters were wrapped in thermally treated and cleaned aluminum foil.

[21] After sampling, filter samples were folded in two, with the exposed side face to face, wrapped in aluminum foil and immediately transported to the laboratory in charge of the sampling site, where they were stored at $-20^{\circ} \mathrm{C}$. Batches of sampled filters and filter blanks were divided into several fractions, enclosed into heated treated aluminum cylinders, and sent by express mail to the various laboratories participating in the analytical work.

\section{Analytical Methods}

[22] Filter samples were analyzed at the University of Aveiro (OC, EC, and GC/MS analysis), Laboratory of Glaciology in Grenoble (inorganic ions and light carboxylates), Technical University of Vienna (levoglucosan, cellulose and HULIS), University of Veszprém (WSOC and HULIS), and University of Heidelberg $\left({ }^{210} \mathrm{~Pb}\right.$ and $\left.{ }^{14} \mathrm{C}\right)$. In this paper details are given on the analysis of major organic fractions (EC, OC, and WSOC) and inorganic ions, whereas for specific organic compounds more details can be found in corresponding dedicated papers of this issue.

\subsection{OC and EC}

[23] Using thermal methods, the various carbon fractions are volatilized by applying sequential heating at increased temperatures. Separation between OC and EC is achieved by initially heating an exposed filter punch under an inert atmosphere, to evaporate first the OC fraction. The remaining fraction is sequentially evaporated/burnt under a gas flow containing $\mathrm{O}_{2}$. This last carbon fraction contains initial EC plus OC that has pyrolyzed during heating under an inert atmosphere, called pyrolytic carbon (PC). The interference between PC and EC can be controlled by continuous evaluation of the blackening of filter using a laser beam and a photodetector, measuring either the filter surface light reflectance or the filter light transmittance. Usually, charring control by transmittance results in lower EC values than by reflectance [Chow et al., 2001]. That is because reflectance only detects charring at the filter surface, while transmittance also detects charring in the filter fiber structure. However, even charring control by transmittance can produce quite different results, depending mainly on the maximum temperature of the heating step under the inert atmosphere. For instance, methodologies, such as the NIOSH (National Institute for Occupational Safety and Health) method, that preheat the filter under $\mathrm{He}$ at $900^{\circ} \mathrm{C}$, have a tendency to result in lower $\mathrm{EC}$ values than methods that have a maximum temperature step at $550-600^{\circ} \mathrm{C}$ [Chow et al., 2001]. This has to be kept in mind when discussing $\mathrm{EC} / \mathrm{OC}$ data.

[24] The OC/EC analysis were done with a thermaloptical technique [Pio et al., 1994; Castro et al., 1999] based on the concept proposed by Huntzicker et al. [1982]. The system includes a quartz tube with two heating zones, a laser, and a nondispersive infrared (NDIR) $\mathrm{CO}_{2}$ analyzer. Filter samples are first exposed to $\mathrm{HCl}$ vapors for several hours to remove carbonates. The filter is then transferred within the first heating zone, which can be heated up to $900^{\circ} \mathrm{C}$. The second heating zone, filled with cupric oxide $(\mathrm{CuO})$, is maintained at $700^{\circ} \mathrm{C}$. Quantitative combustion of volatilized carbon to $\mathrm{CO}_{2}$ is achieved in the second heating zone, where $\mathrm{O}_{2}$ is added. The control of the heating program permits separation of OC into different subfractions, according to their volatility. During heating, the blackness of the filter is monitored by measuring light transmittance through the filter sample with a pulsed laser beam. The analyzer is daily calibrated with standard atmospheres and filters impregnated with known amounts of potassium phthalate.

[25] The program used to analyze the CARBOSOL samples included the following steps: under $\mathrm{N}_{2}$, at $150^{\circ} \mathrm{C}$ for $4 \mathrm{~min}$, at $350^{\circ} \mathrm{C}$ for $4 \mathrm{~min}$, at $600^{\circ} \mathrm{C}$ for $5 \mathrm{~min}$, and from 600 to $250^{\circ} \mathrm{C}$ within $3 \mathrm{~min} ; \mathrm{N}_{2}$ with $4 \%$ of $\mathrm{O}_{2}$, at $350^{\circ} \mathrm{C}$ for $1 \mathrm{~min}$, from 350 to $500^{\circ} \mathrm{C}$ within $7 \mathrm{~min}$, and at $850^{\circ} \mathrm{C}$ for 6 min (Figure 2). With that, the carbonaceous content of the sample can be subdivided into five fractions denoted $\mathrm{OC} 1$ to $\mathrm{OC} 3, \mathrm{PC}$, and $\mathrm{EC}$. PC is organic carbon that has pyrolyzed during heating under inert atmosphere, calculated from the mass of $\mathrm{CO}_{2}$ emitted during the second heating phase under a gas flow containing $\mathrm{O}_{2}$, until the recovering of filter light transmittance (Figure 2). Finally EC is the 


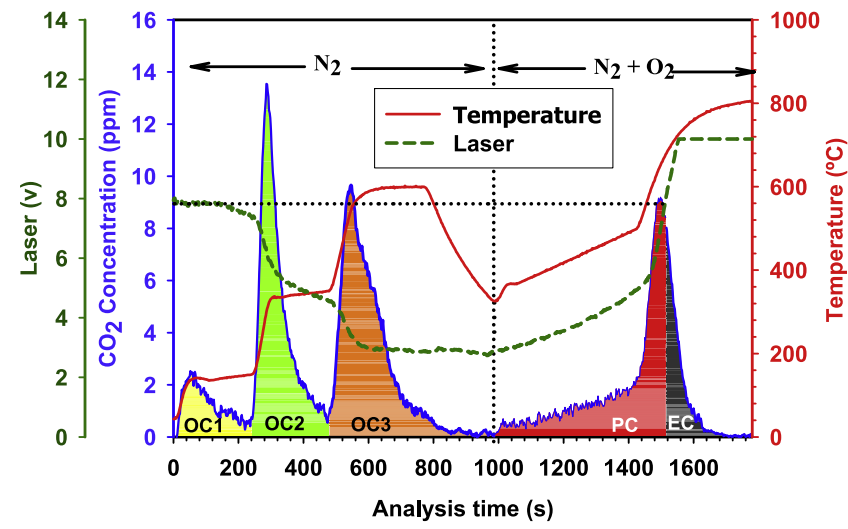

Figure 2. Example of thermogram obtained with method deployed to quantify $\mathrm{OC}$ and its four subfractions $(\mathrm{OC}=$ $\mathrm{OC} 1+\mathrm{OC} 2+\mathrm{OC} 3+\mathrm{PC}$ ) and elemental carbon (EC).

remaining carbon evolving during the last phase of analysis, assumed to correspond to the initial amount of EC present on the filter.

[26] The methodology was tested with samples collected in various environments and with different heating programs. Tests revealed that preheating at $900^{\circ} \mathrm{C}$ without $\mathrm{O}_{2}$ (as in the NIOSH protocol) may render EC results, particularly in rural background samples, $50 \%$ lower than those determined with preheating at $600^{\circ} \mathrm{C}$. The methodology used in this study was intercompared with other methods, revealing, in general, values of EC lying between those obtained with the IMPROVE (Interagency Monitoring of Protected Visual Environments) method of Judith Chow and the NIOSH protocol used in the Sunset Laboratory instrument [Schmid et al., 2001]. Also, in various samples collected at different rural and urban sites, a clear relation between the amount of oxygenated organic matter present in aerosol and the quantity of PC formed during heating process was observed. This suggests that charring is probably strengthened by reaction between $\mathrm{O}$ and $\mathrm{H}$ atoms present in the organic oxygenated molecules.

[27] Detection limits depend on the variability of filter blanks (adsorption of volatile organic compounds, VOCs, during storage and transport) and the noise of the laser and $\mathrm{CO}_{2}$ analyzer. The average field filter blanks ranged from $320 \mu \mathrm{g}$ for SBO and PDD, to $600 \mu \mathrm{g}$ and $721 \mu \mathrm{g}$ at AZO and KPZ, respectively. On the basis of the variability of blank filter batches, the detection limit of OC (3 times the standard deviation) was found between $30 \mathrm{ng} \mathrm{m}^{-3}$ (AVE) and $90 \mathrm{ng} \mathrm{m}^{-3}$ (AZO). Evaluation of thermograms shows that masses of carbon lower than $1 \mu \mathrm{g}$ are difficult to quantify, with the applied methodology, for low filter particle deposits. That corresponds to a detection limit of $30 \mathrm{ng} \mathrm{m}^{-3}$ for EC.

\subsection{Inorganic Ions}

[28] A piece of each filter (1 to $3 \mathrm{~cm}^{2}$ of a total surface of 150 or $400 \mathrm{~cm}^{2}$ ) was extracted with ultra pure Milli-Q water. For cations a Dionex 500 chromatograph equipped with a CS12 separator column was used. For $\mathrm{Na}^{+}, \mathrm{NH}_{4}^{+}, \mathrm{K}^{+}$, $\mathrm{Mg}^{2+}$, and $\mathrm{Ca}^{2+}$ the detection limit was close to $1 \mathrm{ng} \mathrm{m}^{-3}$. For anions a Dionex 600 equipped with an AS11 separator column was run with a quaternary gradient of eluents $\left(\mathrm{H}_{2} \mathrm{O}\right.$, $\mathrm{NaOH}$ at 2.5 and $100 \mathrm{mM}$, and $\mathrm{CH}_{3} \mathrm{OH}$ ) as detailed by Ricard et al. [2002]. For inorganic anions such as $\mathrm{SO}_{4}^{2-}$, $\mathrm{NO}_{3}^{-}$, and $\mathrm{Cl}^{-}$, the detection limit was close to $1 \mathrm{ng} \mathrm{m}^{-3}$. To estimate the part of sulfate related to DMS oxidation at marine sites we also investigated methanesulfonate (MSA) levels.

\subsection{Water Soluble Organic Carbon}

[29] Determination of WSOC includes soaking a spot of filter $\left(4.5 \mathrm{~cm}^{2}\right)$ in $25 \mathrm{~mL}$ of Milli-Q water for 2 hours; soaking removed all WSOC from the filter spot. After drying the extracted filter spot was analyzed for total carbon, TC, by an Astro 2100 TOC analyzer in the solid mode. The determination involved catalytic burning at $680^{\circ} \mathrm{C}$ in $\mathrm{O}_{2}$, followed by NDIR detection of the evolved $\mathrm{CO}_{2}$ [Varga et al., 2001]. An unextracted spot of the filter of identical size was also analyzed for TC with the same analytical methodology The WSOC concentration was derived indirectly as the difference of the two measurements. The detection limit of the TC measurements was $2 \mu \mathrm{gC}$, corresponding to a detection limit for WSOC of about $50-100 \mathrm{ngC} \mathrm{m}^{-3}$.

\subsection{Other Determinations}

[30] As for WSOC, portions of filters were extracted with Milli-Q water and filtered through a $0.22 \mu \mathrm{m}$ pore size filter for HULIS determinations. Specific details of the extraction/ analytical methodology are reported in the paper from Lukács et al. [2007]. A specific adaptation of this methodology was developed and applied at the Technical University of Vienna by using adsorption/elution with two separation steps, the first on $\mathrm{C} 18$, the second on ionexchanger material, permitting the separated determination of water extractable HULIS and caustic soda $(0.1 \mathrm{~N})$ extractable HULIS. Details of this methodology are given by Limbeck et al. [2005] and by Feczko et al. [2007].

[31] C2-C5 dicarboxylic acids were investigated together with inorganic ions by ionic chromatography (section 3.2). Investigated dicarboxylates are oxalate $\left({ }^{-} \mathrm{OOCCOO}^{-}\right)$, malate ( $\left.{ }^{-} \mathrm{OOCCH}_{2} \mathrm{CHOHCOO}^{-}\right)$, malonate $\left({ }^{-} \mathrm{OOCCH}_{2} \mathrm{COO}^{-}\right)$, succinate $\left({ }^{-} \mathrm{OOC}\left(\mathrm{CH}_{2}\right)_{2} \mathrm{COO}^{-}\right)$, glutarate $\left({ }^{-} \mathrm{OOC}\left(\mathrm{CH}_{2}\right){ }_{3} \mathrm{COO}^{-}\right)$, and tartarate $\left({ }^{-} \mathrm{OOC}(\mathrm{CHOH})_{2} \mathrm{COO}^{-}\right)$. For all carboxylates the detection limit is close to $1 \mathrm{ng} \mathrm{m}^{-3}$ and is related to the accuracy of the ion chromatography. More specific information concerning analysis of these minor species is given by Legrand et al. [2007].

[32] Free cellulose of aerosol was determined via an enzymatic saccharification reaction followed by glucose determination [Puxbaum and Tenze-Kunit, 2003]. More specific details of this methodology applied for CARBOSOL samples can be found in Sánchez-Ochoa et al. [2007]. Of the sugar anhydrides, levoglucosan was determined by highperformance liquid chromatography, HPLC, analysis; pooled monthly samples were reanalyzed with a modified method [see Puxbaum et al., 2007].

[33] Pooled samples, representing monthly average conditions, corresponding to the first year of aerosol sampling at the six sites, were extracted for 24 hour periods with dichloromethane, and then fractionated by flash chromatography with eluents of increasing polarity through activated 
silica gel (230-400 mesh) under $\mathrm{N}_{2}$ flow, resulting into five fractions (aliphatics, aromatics, aldehydes and ketones, alcohols, and acids). Further details of the method and analytical protocol are given by Oliveira et al. [2007]. Each of the five fractions was analyzed by GC/MS, after derivatization for alcohols and acids, with the aim of identifying and quantifying nonvolatile particulate tracer organic species.

[34] ${ }^{210} \mathrm{~Pb}$ was analyzed in all individual filter samples by $\gamma$-spectrometry following the procedure of Wagenbach et al. [1988]. Disregarding errors in the sampling volume, the overall analytical uncertainty was found to be controlled by the statistical counting error and ranged from 5\% at mountain sites during background conditions, to $3 \%$ at continental low-elevation sites. ${ }^{14} \mathrm{C}$ analyses were performed on 13 individual samples selected from PDD and SIL sites by season and the continental air mass influence (as indicated by the respective ${ }^{210} \mathrm{~Pb}$ level). Additional radiocarbon results were obtained on 5 composite filter samples from AVE, KPZ and SBO, mainly distinguished by winter and summer season, respectively. After removal of particulate carbonates by exposition to an atmosphere with $\mathrm{HCl}$ vapors, carbonate-free filters were burned in a dynamic gas stream, followed by accelerator mass spectrometry of produced graphite targets at University of Vienna (VERA) to yield (standard) pmC (percent modern carbon) values of the total organic carbon content with typical relative uncertainties ranging between 5 and $10 \%$.

\section{Results and Discussion}

[35] In this paper summer refers to months from April to September, and winter to the 6 remaining months of the year. All concentrations are reported at standard conditions $\left(0^{\circ} \mathrm{C}\right.$ and one atmosphere $)$ to account for dilution with altitude.

\subsection{Background Information on Sampling Sites Derived From Radioisotopes and Air Mass Origins at the Sites}

[36] CARBOSOL sites include the oceanic site of AZO, two surface sites located at the Atlantic coast (AVE) and in the central European plains (KPZ), and three mountain sites located at 1200-1450 m (SIL and PDD) and $3100 \mathrm{~m}$ (SBO) elevation.

[37] Within the CARBOSOL network, concurrent analyses of the ${ }^{210} \mathrm{~Pb}$ variability were mainly aimed at assessing seasonal changes and systematic intersite differences present in the chemical data, in terms of vertical air mass exchange intensity and mean accumulation of continental (gaseous) emissions with altitude and increasing distance to the Atlantic coast, respectively [Hammer et al., 2007]. The aerosol borne ${ }^{210} \mathrm{~Pb}$ is produced at a fixed conversion rate of $18 \%$ per day from its radioactive precursor gas ${ }^{222} \mathrm{Rn}$, which in turn is emitted from the soil at an almost spatiotemporal uniform rate. Thus ${ }^{210} \mathrm{~Pb}$ may be used as surrogate species for a natural secondary aerosol body of solely continental sources origin, which spatiotemporal variability are mainly governed by air mass transport and the relevant continental catchment areas. It is expected, therefore, that an apparent close covariance of ${ }^{210} \mathrm{~Pb}$ with chemical aerosol components may be driven by these issues.
[38] AZO is located in the middle of the north Atlantic Ocean and collected aerosol represents here the background marine atmosphere, with levels influenced frequently by long-range transport from North America, with less frequent advections from Europe and North Africa [Honrath et al., 2004]. As expected ${ }^{210} \mathrm{~Pb}$ exhibits low values in AZO compared to others CARBOSOL sites (Table 1).

[39] AVE is located at the western European Atlantic coast and is under the influence of air masses traveling from the ocean, having a relatively mild climate. However, during CARBOSOL, the site was also frequently under influence of air masses having a recent continental origin, as clearly revealed by concurrent ${ }^{210} \mathrm{~Pb}$ measurements showing weekly atmospheric activities significantly above those expected for typical marine situations. ${ }^{210} \mathrm{~Pb}$ average values measured in AVE (Table 1) are similar to multiannual average values at other coastal areas of the Iberian Peninsula $\left(0.54 \mathrm{mBq} \mathrm{m}^{-3}\right.$ in Malaga [Dueñas et al., 2005], $0.62 \mathrm{mBq}$ $\mathrm{m}^{-3}$ in Granade [Camacho-García, 2000]). Furthermore the ${ }^{210} \mathrm{~Pb}$ record at AVE does not reveal weekly sampling periods which would have clearly stood out as influenced only by pristine marine air; hence continental sources are expected to substantially contribute to the atmospheric load at AVE.

[40] ${ }^{210} \mathrm{~Pb}$ overall means at surface sites of AVE and KPZ differ significantly because of continental accumulation. However, no definitive seasonal cycles of ${ }^{210} \mathrm{~Pb}$ appears to be developed at AVE and only a rather subdued one is found at (the much less continuously sampled) KPZ site. Stable conditions primarily developing during the winter half year are admittedly less sensitively seen by weekly enhanced ${ }^{210} \mathrm{~Pb}$ levels than by its locally produced ${ }^{222} \mathrm{Rn}$ precursor gas. Indeed, hourly resolved ${ }^{222} \mathrm{Rn}$ monitoring at the AVE (not shown) revealed clearly higher activities during fall and winter, associated with substantial source contributions from emissions into the local boundary layer. Therefore at least part of the enhanced winter levels of chemical species observed at the low-elevation AVE and $\mathrm{KPZ}$ sites are driven by the reduced vertical mixing intensity during that season.

[41] As indicated by the seasonal ${ }^{210} \mathrm{~Pb}$ means (Table 1), regular seasonal cycles (summer maxima) are clearly seen at the mountain sites PDD, SIL and SBO, revealing systematic activity differences associated with the continentality and the altitude of the sites.

\subsection{Contribution of Organics, Versus Inorganics, to PM2.5 Aerosol Mass}

[42] To evaluate the relative abundance of organic matter with respect to inorganic ions present in aerosol collected at the CARBOSOL sites, we report in Figure 3 seasonal averaged levels of EC, total mass of particulate organic matter (denoted $\mathrm{OM}$ ) and total mass of water soluble inorganic ions (denoted WSII). Common values available in the literature to convert OC into OM range between 1.2 and 1.6 [Hughes et al., 1998; Turpin et al., 2000], up to 2 or more [Turpin and Lim, 2001]. During CARBOSOL, elemental analysis were performed in WSOC aerosol collected at AVE indicating values of 1.7 in winter and 1.9 in summer [Duarte, 2006]. Considering the mean ratio of WSOC to OC of $\sim 56 \%$ at Aveiro (see section 4.5 ), the factor used to convert OC into OM would not exceed 1.6 at this site. 
Table 1. Summer (S) and Winter (W) Averaged Levels at the CARBOSOL Sites of ${ }^{210} \mathrm{~Pb}$, Total Organic Mass (OM), Total Water Soluble Inorganic Ions (WSII) and Mass Ratio Between OM and WSII

\begin{tabular}{lcccc}
\hline \multicolumn{1}{c}{ Site } & ${ }^{210} \mathrm{~Pb}, \mathrm{mBq} / \mathrm{m}^{3}$ & $\mathrm{OM}, \mathrm{ng} / \mathrm{m}^{3}$ & WSII, ng/m & $\begin{array}{c}(\mathrm{OM}) / \text { WSII, } \\
\mathrm{ng} / \mathrm{ng}\end{array}$ \\
\hline AZO S & 0.32 & 610 & 5200 & 0.19 \\
AZO W & $0.23^{\mathrm{a}}$ & 430 & 9100 & 0.09 \\
AVE S & 0.53 & 4900 & 7400 & 0.72 \\
AVE W & 0.53 & 11900 & 5900 & 2.23 \\
PDD S & 0.47 & 3800 & 3700 & 1.20 \\
PDD W & 0.25 & 1260 & 2200 & 0.80 \\
SIL S & 0.62 & 5400 & 6800 & 0.98 \\
SIL W & 0.43 & 2200 & 4600 & 0.66 \\
SBO S & 0.49 & 2200 & 2300 & 1.16 \\
SBO W & 0.32 & 770 & 920 & 1.13 \\
KPZ S & 0.77 & 7800 & 6900 & 1.20 \\
KPZ W & 0.84 & 11800 & 15100 & 0.99 \\
\hline
\end{tabular}

${ }^{\mathrm{a}}$ No fully continuous data set.

Although this ratio would vary over time and from site to site, because of lack of more information, a constant value of 1.6 was used here to calculate $\mathrm{OM}$ at all sites.

[43] The total PM2.5 mass was determined at AVE, by filter weighting at $50 \%$ relative humidity, showing an annual mean value of $23 \mu \mathrm{g} \mathrm{m}^{-3}$, a value which lies in the range of those observed by Van Dingenen et al. [2004] at rural $\left(9\right.$ to $20 \mu \mathrm{g} \mathrm{m}^{-3}$ ) and near-city $\left(20\right.$ to $25 \mu \mathrm{g} \mathrm{m}^{-3}$ ) sites in Europe. Annual mean total PM10 mass at AVE $\left(\sim 37 \mu \mathrm{g} \mathrm{m}^{-3}\right)$ is close to typical values observed at near city sites in Europe ( 28 to $37 \mu \mathrm{g} \mathrm{m}^{-3}$ [Van Dingenen et al., 2004]). The noncarbonated total carbonaceous mass (EC plus OM) contributes on a yearly basis to $41 \%$ of the PM2.5 aerosol mass at AVE, in good agreement with the averaged value previously derived for European urban background and rural sites (31\% [Putaud et al., 2004]). At AVE, carbonaceous aerosol dominates the PM2.5 mass during winter $(51 \%)$ whereas its contribution is weakened in

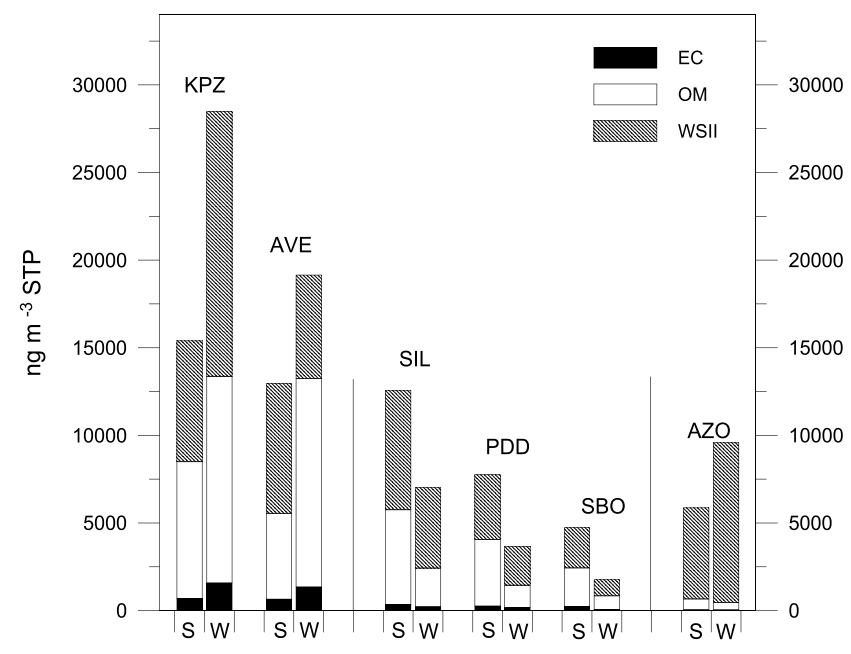

Figure 3. Mean summer (S) and winter (W) levels of EC, $\mathrm{OM}$, and total water soluble inorganic ions (WSII) at the six CARBOSOL sites. At AZO, AVE, SBO, and KPZ a PM 2.5 inlet was used, and at PDD and SIL a PM 10 inlet was used.

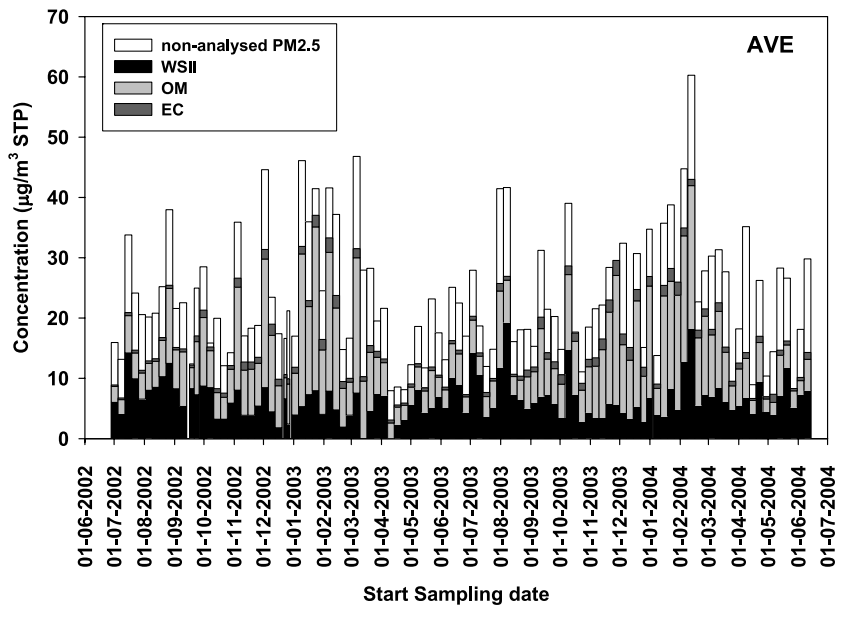

Figure 4. Weekly distribution of the PM2.5 mass along with the contribution of noncarbonated total carbonaceous mass $(\mathrm{EC}+\mathrm{OM})$ and inorganic mass (WSII) over 2 years at AVE.

summer $(29 \%)$. As seen in Figure 4 the mass of analyzed inorganic ions (WSII) plus the carbonaceous matter (EC plus OM) represents on average $70 \%$ of the PM2.5 aerosol mass at AVE. The remaining fraction of the PM2.5 mass, accounting here for $30 \%$, is generally attributed to water bounded to hygroscopic inorganic and organic material. At $50 \%$ relative humidity, atmospheric aerosol can contain up to $30 \%$ of water. Given the relative large amount of sea-salt aerosol, sulfate, nitrate and WSOC at AVE the hygroscopicity of the aerosol may explain the differences between identified and total mass of PM2.5 [Harrison et al., 2003].

[44] One part of the nonidentified material can also result from the presence of unidentified species (water-insoluble dust material) or from an underestimation of the factor used to convert OC into OM. It can be emphasized that Putaud et al. [2004] applying a factor of 1.4 to convert OC into OM, obtained an unidentified fraction of $20 \%$ of PM2.5 in Europe. A crude estimate of the mass of mineral dust present in the European atmosphere can be derived as 4.5 times the non-sea-salt calcium (nss-Ca ${ }^{2+}$ ) level [Putaud et al., 2004]. The level of nss-Ca ${ }^{2+}$ is close to $140 \mathrm{ng} \mathrm{m}^{-3}$ and $95 \mathrm{ng} \mathrm{m}^{-3}$ at AVE in summer and winter, respectively (section 4.3.3). On this basis, we can conclude that the total mineral dust cannot account for more than 1 to $3 \%$ of the PM2.5 mass, since a significant fraction of mineral dust has been identified (a fraction of $\mathrm{Mg}^{2+}$ and $\mathrm{SO}_{4}^{2-}$, for instance, see section 4.3.3).

[45] Apart from AVE, total PM2.5 or PM10 masses were not investigated at other continental CARBOSOL sites. At these sites the evaluation of the absolute contributions of organic matter and inorganic ions to the total PM2.5 mass was thus not possible, but the relative contribution of OM and total inorganic ions can be still examined. The OM/ WSII ratios reported in Table 1 indicate that, except at the marine site of AZO where inorganic ions largely exceed the organic matter, $\mathrm{OM}$ is similar to total inorganic ions in the studied European atmosphere. As seen in Figure 5, the dominant presence of ions with respect to OM, in Azores, is related to a decrease of OM, as well as a still large level of inorganic ions related to sea salt but also non-sea-salt sulfate 


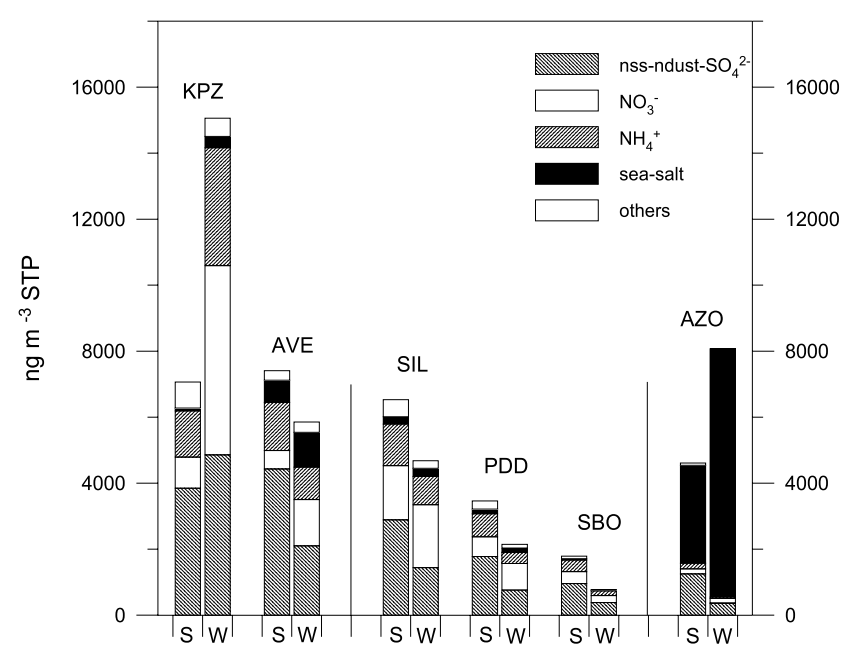

Figure 5. Mean summer (S) and winter (W) levels of nonsea-salt nondust sulfate, nitrate, ammonium, sea salt, and other ions at the six CARBOSOL sites. At AZO, a few samples containing very high sodium content were discarded since they give too high uncertainty in calculating non-sea-salt sulfate. At AZO, AVE, SBO, and KPZ a PM 2.5 inlet was used, and at PDD and SIL a PM 10 inlet was used.

(see section 4.3.2). Since we found that over continental Europe most of OC is water soluble (see section 4.5) it can be concluded that in addition to sulfate, OC aerosol has to be also considered in discussing the role of cloud nucleation particles on climate there. At continental sites the $\mathrm{OM}$ and WSII masses remain rather similar, at least in summer (Table 1). In the following we examine and discuss the observed spatiotemporal variations in the load and composition of the inorganic (section 4.3) and organic fractions (section 4.4) of aerosol collected at the six CARBOSOL sites.

\subsection{Seasonal and Spatial Variations of the Inorganic Aerosol Load and Composition}

[46] Summer and winter levels of inorganic ions at the CARBOSOL sites are summarized in Figure 5. The sum of ions was subdivided into five key fractions: nitrate, ammonium, sea salt, fraction of sulfate not related to sea salt and mineral dust (nss-ndust- $\mathrm{SO}_{4}^{2-}$ ), and others (calculated by subtracting the four preceding fractions to the sum of ions). 4.3.1. Sea Salt

[47] Because of the presence of a leachable fraction of $\mathrm{Na}$ in mineral dust aerosol, evaluation of the sea-salt mass cannot be conducted in the same way at continental sites and marine sites like AZO. Considering the mass ratio of $\mathrm{Ca}$ to $\mathrm{Na}$ in seawater $(0.038)$ and that continental aerosol contains far more calcium than leachable sodium [Legrand et al., 2002], examination of $\mathrm{Na}^{+}$and $\mathrm{Ca}^{2+}$ levels reported in Table 2 indicates that at AZO and AVE, where sodium dominates calcium, sodium can be used as an unambiguous tracer of the sea-salt aerosol. At these two sites, the mass fraction of sea salt was therefore calculated by adding to sodium, chloride and the sea-salt contributions of magnesium, calcium, potassium and sulfate, as follows:

$$
\begin{aligned}
{[\text { Sea salt }]=} & {\left[\mathrm{Na}^{+}\right]+\left[\mathrm{Cl}^{-}\right]+0.12\left[\mathrm{Na}^{+}\right] } \\
& +0.038\left[\mathrm{Na}^{+}\right]+0.038\left[\mathrm{Na}^{+}\right]+0.25\left[\mathrm{Na}^{+}\right]
\end{aligned}
$$

with $0.12,0.038$, and 0.25 being the mass ratios in seawater of magnesium to sodium, calcium to sodium, as well as potassium to sodium and sulfate to sodium, respectively.

[48] As seen in Table 2, the observed levels of $\mathrm{Cl}^{-}$at the two marine sites in winter are close to the expected levels considering the mass ratio of $\mathrm{Cl}^{-}$to $\mathrm{Na}^{+}$in seawater (1.8). Conversely note that a depletion of chloride relative to sodium can be observed in summer. At these sites, $\mathrm{Mg}^{2+}$ appears to be mostly related to sea-salt aerosol, whereas a large fraction of $\mathrm{Ca}^{2+}$ and $\mathrm{K}^{+}$are present in excess with respect to sea salt.

[49] At KPZ, SIL, and PDD, calcium levels are similar, or higher than those of sodium, suggesting a significant presence of aerosols related to soil emissions, and equation (1) does not remain valid since the observed sodium level there cannot be attributed to sea salt only. Since magnesium is the second more abundant cation in sea-salt aerosol, we tentatively estimated its fraction related to dust input; to do this we examined the relationship between $\mathrm{Mg}^{2+}$ and $\mathrm{Ca}^{2+}$ at these sites in summer, a season during which sea-salt input would be minimum and dust input maximum. A consistent relationship between magnesium and calcium is observed at the three sites, with a slope of the linear relationship varying from 0.10 at KPZ and PDD, to 0.13

Table 2. Seasonally Averaged Concentrations of Sodium, Sea-Salt Sodium $\left(\mathrm{Na}_{\mathrm{m}}^{+}\right)$, Chloride, as Well as Magnesium, Calcium, and

\begin{tabular}{|c|c|c|c|c|c|c|c|c|c|c|}
\hline Sites & $\mathrm{Na}^{+}$ & $\mathrm{Na}_{\mathrm{m}}{ }^{+}$ & $\mathrm{Cl}^{-}$ & $\mathrm{Mg}^{2+}$ & nss-Mg ${ }^{2+}$ & $\mathrm{Ca}^{2+}$ & nss-Ca ${ }^{2+}$ & $\mathrm{K}^{+}$ & nss-K ${ }^{+}$ & nss-ndust-K ${ }^{+}$ \\
\hline AZO S & 1160 & 1160 & 1290 & 144 & $\mathrm{~ns}$ & 88 & 45 & 62 & 18 & 15 \\
\hline AZO W & 2400 & 2400 & 4100 & 270 & ns & 113 & 27 & 100 & 12 & 10 \\
\hline AVE S & 400 & 400 & 87 & 52 & ns & 158 & 142 & 158 & 142 & 125 \\
\hline AVE W & 340 & 340 & 560 & 47 & ns & 107 & 94 & 230 & 210 & 200 \\
\hline PDD S & 130 & 81 & 22 & 29 & 19 & 170 & $\sim 170$ & 57 & 54 & 37 \\
\hline PDD W & 95 & 64 & 29 & 15 & 7.5 & 72 & $\sim 72$ & 29 & 26 & 21 \\
\hline SIL S & 240 & 113 & 57 & 51 & 37 & 350 & $\sim 350$ & 119 & 115 & 77 \\
\hline SIL W & 156 & 116 & 79 & 29 & 15 & 151 & $\sim 151$ & 61 & 57 & 44 \\
\hline SBO S & 21 & $<21^{\mathrm{b}}$ & 16 & $29^{\mathrm{b}}$ & & $310^{\mathrm{b}}$ & & 34 & $\sim 34^{\mathrm{b}}$ & \\
\hline SBO W & 12 & $<12^{\mathrm{b}}$ & 5 & $12^{\mathrm{b}}$ & & $133^{b}$ & & 13 & $\sim 13^{\mathrm{b}}$ & \\
\hline KPZ S & 79 & 48 & 21 & 63 & 58 & 530 & $\sim 530$ & 173 & 172 & 110 \\
\hline KPZ W & 116 & 76 & 230 & 31 & 22 & 197 & $\sim 197$ & 330 & 320 & 300 \\
\hline
\end{tabular}
Potassium Cations and Their Non-Sea-Salt Contributions ${ }^{\text {a }}$

${ }^{\mathrm{a}}$ Unit is $\mathrm{ng} \mathrm{m}^{-3}$; ns, nonsignificant.

${ }^{\mathrm{b}}$ See text. 
Table 3. Seasonally Averaged Concentrations of Sulfate, NonSea-Salt Sulfate, Non-Sea-Salt and Nondust Sulfate, MSA, and Biogenic Sulfate ${ }^{\mathrm{a}}$

\begin{tabular}{|c|c|c|c|c|c|}
\hline Sites & $\mathrm{SO}_{4}^{2-}$ & nss-SO $\mathrm{SO}_{4}^{2-}$ & nss-ndust-SO $\mathrm{SO}_{4}^{2-}$ & MSA & $\mathrm{SO}_{4}^{2-}$ bio \\
\hline AZO S & 1540 & 1260 & 1250 & 40 & 270 \\
\hline AZO W & 890 & 370 & 365 & 6 & 32 \\
\hline AVE S & 4540 & 4440 & 4430 & 72 & 480 \\
\hline AVE W & 2200 & 2100 & 2100 & nd & 0 \\
\hline PDD S & 1800 & 1780 & 1780 & nd & 0 \\
\hline PDD W & 780 & 760 & 760 & nd & 0 \\
\hline SIL S & 3040 & 3010 & 2990 & nd & 0 \\
\hline SIL W & 1480 & 1450 & 1440 & nd & 0 \\
\hline SBO S & 960 & 960 & 960 & nd & 0 \\
\hline SBO W & 380 & 380 & 380 & nd & 0 \\
\hline KPZ S & 3880 & 3870 & 3850 & nd & 0 \\
\hline KPZ W & 4890 & 4870 & 4860 & nd & 0 \\
\hline
\end{tabular}

${ }^{\mathrm{a}} \mathrm{Unit}$ is $\mathrm{ng} \mathrm{m}^{-3}$. At $\mathrm{AZO}$, a few samples containing very high sodium content were discarded since they give too high uncertainty in calculating non-sea-salt sulfate. nd, not determined.

at KPZ. On this basis we estimated the sea-salt fraction of magnesium $\left(\mathrm{Mg}_{\mathrm{m}}^{2+}\right)$ by subtracting 0.12 times the $\mathrm{Ca}^{2+}$ level to the $\mathrm{Mg}^{2+}$ level. The sea-salt fraction of sodium $\left(\mathrm{Na}_{\mathrm{m}}^{+}\right)$is thereafter estimated by dividing $\mathrm{Mg}_{\mathrm{m}}^{2+}$ by the seawater magnesium to sodium ratio $(0.12)$. At these three sites the sea-salt fraction was estimated as follows:

$$
\begin{aligned}
{[\text { Sea salt }]=} & {\left[\mathrm{Na}_{\mathrm{m}}{ }^{+}\right]+\left[\mathrm{Cl}^{-}\right]+0.12\left[\mathrm{Na}_{\mathrm{m}}{ }^{+}\right] } \\
& +0.038\left[\mathrm{Na}_{\mathrm{m}}{ }^{+}\right]+0.038\left[\mathrm{Na}_{\mathrm{m}}{ }^{+}\right]+0.25\left[\mathrm{Na}_{\mathrm{m}}{ }^{+}\right],
\end{aligned}
$$

with $\left[\mathrm{Na}_{\mathrm{m}}^{+}\right]=\left(\left[\mathrm{Mg}^{2+}\right]-0.12\left[\mathrm{Ca}^{2+}\right]\right) / 0.12$.

[50] Surprisingly at SBO the $\mathrm{Ca}^{2+}$ level is some ten times higher than the $\mathrm{Na}^{+}$one (Table 2). Furthermore, whereas the sodium level at SBO is five times lower than at PDD, calcium and magnesium exhibit no decrease between the two sites. It is very likely that the construction activities using concrete, a material rich in calcium, that took place at SBO during the CARBOSOL project have led to contamination of aerosol samples. Anyway, the low level of sodium at SBO (12 to $\left.20 \mathrm{ng} \mathrm{m}^{-3}\right)$ indicates that the sea-salt contribution is very low at this site and, as an upper limit, we have applied equation (1) to estimate its contribution there.

[51] As expected, sea salt dominates inorganic ions present in PM2.5 aerosol at the marine site of AZO in winter $(94 \%)$ and to a lesser extent in summer (64\%) (Figure 5). At the coastal site of AVE sea salt is less abundant than at AZO in PM2.5 aerosol and its contribution to total inorganic ions is reduced ( 9 and $18 \%$ in summer and winter, respectively). At continental sites the contribution of sea salt to inorganic ions present in PM2.5 aerosol does not exceeds 5\% (Figure 5). At PDD and SIL, its contribution in PM 10 aerosol is $5 \%$ and $4 \%$, respectively. This increasing contribution of sea salt from KPZ to SIL and PDD may reflect a larger input of sea salt in western Europe than in central Europe, though the size fraction of sampled aerosol is not the same at three sites.

\subsubsection{Non-Sea-Salt, Nondust, Sulfate, Ammonium, and Nitrate}

[52] The non-sea-salt fraction of sulfate is calculated by subtracting the sulfate sea-salt fraction taken as 0.25 times the sea-salt fraction of sodium. As seen in Table 3 the seasalt sulfate contribution is large at AZO (19\% and 59\% of total sulfate in summer and winter, respectively) and becomes weaker at more continental sites including AVE ( 2 and $4 \%$ in summer and winter, respectively). At continental sites another nonsubmicrometer fraction of sulfate, related to mineral dust (gypsum), has to be considered. In crustal rock and average soils a mass ratio of sulfate to calcium of 0.05 has been proposed by Mason and Moore [1984]. On this basis, we estimated the contribution of dust to sulfate by applying a sulfate to nss- $\mathrm{Ca}^{2+}$ ratio of 0.05 (Table 3).

[53] At continental sites, nss-ndust- $\mathrm{SO}_{4}^{2-}$ represents from $20 \%$ of the (WSII $+\mathrm{EC}+\mathrm{OM}$ ) mass, at $\mathrm{KPZ}$, to $24 \%$, at $\mathrm{SBO}$. Although it is clear that nss-ndust- $\mathrm{SO}_{4}^{2-}$ is mainly related to anthropogenic $\mathrm{SO}_{2}$ emissions in continental Europe, the oxidation of marine DMS emissions from phytoplankton has to be considered at the marine sites of AVE and AZO. Aiming to evaluate this biogenic sulfate fraction, we report in Table 3 MSA levels at AZO and AVE. Under analytical IC conditions used in this study, the MSA peak however is not always adequately separated from the pyruvate peak. Given the low level of pyruvic acid observed in aerosols over the Pacific ocean by using GCMS analysis (0.2 $\mathrm{ng} \mathrm{m}^{-3}$ [Kawamura and Usukura, 1993] and $0.13 \mathrm{ng} \mathrm{m}^{-3}$ [Sempéré and Kawamura, 2003]) we can, nevertheless, assume that at these sites, where biogenic sulfate is expected to be significant, the several tens of $\mathrm{ng} \mathrm{\textrm {m } ^ { - 3 }}$ reported in Table 3 as MSA are correct. In winter it is also likely that MSA levels are still correct at the remote marine site of AZO. The situation is less clear at AVE regarding the large levels of $\mathrm{OM}$ observed at that season (Table 1). To evaluate the biogenic fraction of sulfate we used the relationship between the ratio of MSA to nssSO and air temperature observed by Bates et al. [1992] in the remote south Pacific ocean $\left(\mathrm{MSA} / \mathrm{nssSO}_{4}^{2-}\right.$ (in \%) $=-1.5 \mathrm{~T}$ (in $\left.{ }^{\circ} \mathrm{C}\right)+42.2$ ). Given the mean surface air temperature at the AZO $\left(18^{\circ} \mathrm{C}\right)$ a MSA to $n s s \mathrm{SO}_{4}^{2-}$ molar ratio of $15 \%$ is expected for the biogenic sulfate fraction. This value is

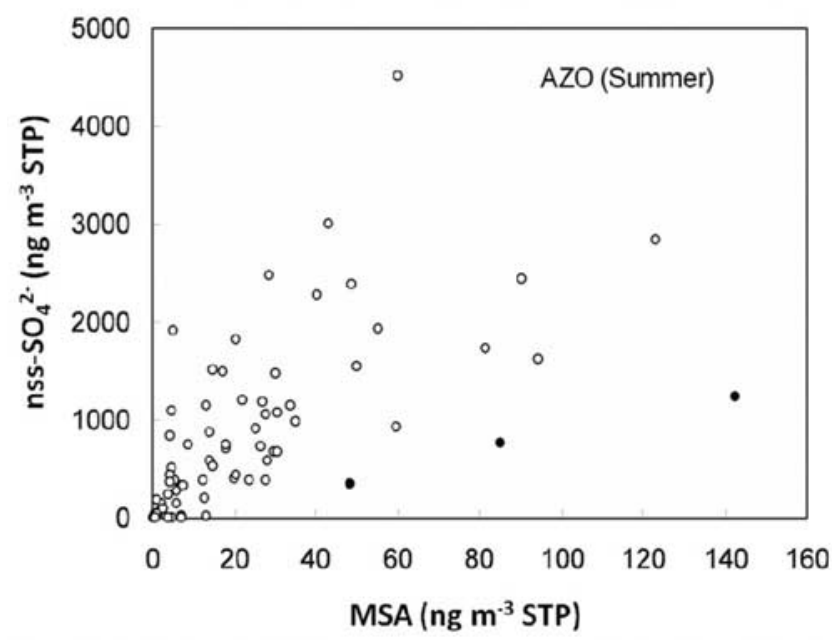

Figure 6. Non-sea-salt sulfate (nss- $\mathrm{SO}_{4}^{2-}$ ) versus MSA levels (in $\mathrm{ng} \mathrm{m}^{-3}$ ), at Azores in summer. Solid circles indicate the lower envelope of the correlation between the two species which leads to a MSA to nss- $\mathrm{SO}_{4}^{2-}$ mass ratio close to $15 \%$ (see text). 

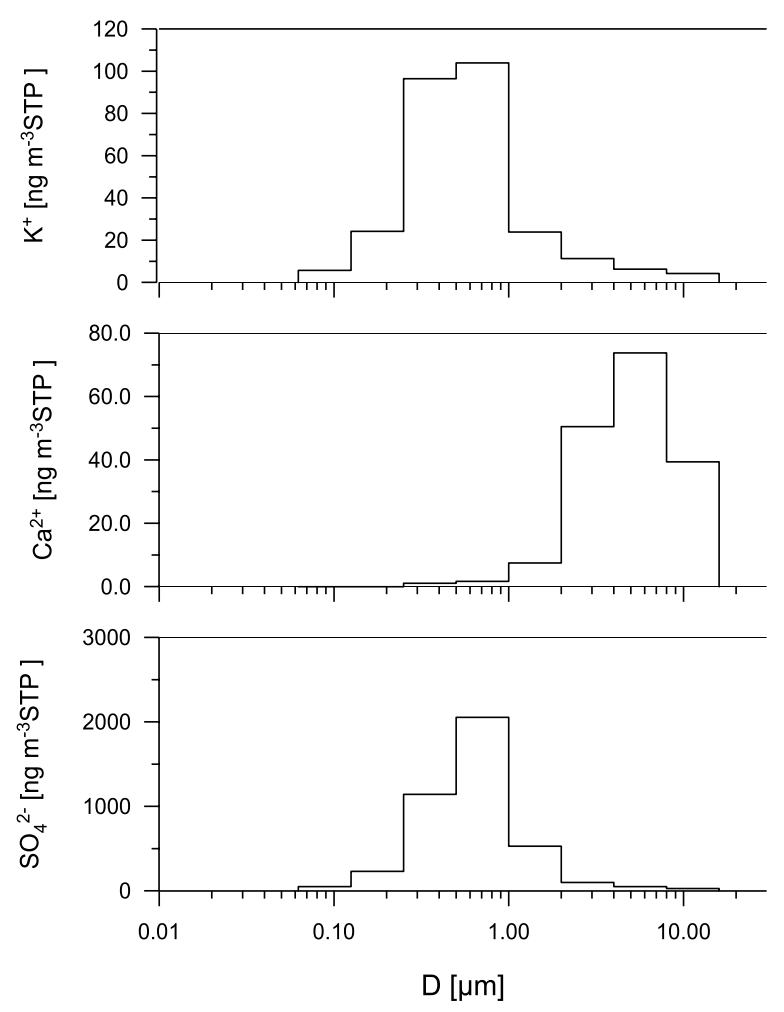

Figure 7. Mass size distribution of potassium, calcium and sulfate in a sample collected at KPZ between 29 March and 4 April 2004. The $y$ axis refers to $\mathrm{dC} / \mathrm{d} \log \mathrm{D}$.

consistent with the slope of the lower envelope of the relationship observed between $\mathrm{NssSO}_{4}^{2-}$ and MSA levels at AZO in summer (Figure 6) and was here used as a crude estimate to calculate biogenic sulfate fraction at AZO and AVE. This biogenic fraction ranges from 10 to $17 \%$ of total sulfate in summer at AVE and AZO, respectively (Table 3). In winter the biogenic fraction accounts for only $4 \%$ of total sulfate at AZO and was assumed to be null at AVE, considering the possible overlaps of pyruvic acid there.

[54] The level of Elemental Carbon strongly decreases from AVE to AZO (from $1000 \mathrm{ng} \mathrm{m}^{-3}$ to $43 \mathrm{ng} \mathrm{m}^{-3}$, Table 4), whereas anthropogenic sulfate is only decreased by a factor of 5 (Table 3). Assuming that most of EC present at AZO is long-range transported from continents, the relatively low decrease of anthropogenic sulfate between AVE and AZO remains difficult to explain by the ongoing oxidation of $\mathrm{SO}_{2}$ during the transport from continents and suggests the existence of another source for this species at AZO. A possible source of sulfate, which may become significant with respect to present-day $\mathrm{SO}_{2}$ emissions from continents, is $\mathrm{SO}_{2}$ emission by ship traffic. To investigate this possibility we used the transport-chemistry EMEP model to simulate sulfate concentrations over Europe for 2002, with and without ship emissions taken into account. The results were analyzed at $40^{\circ} \mathrm{N} 20^{\circ} \mathrm{W}$ (i.e., at an equal distance between AVE and AZO) (unpublished results). The simulated nss- $\mathrm{SO}_{4}^{2-}$ levels $\left(1040 \mathrm{ng} \mathrm{m}^{-3}\right.$ in summer, $300 \mathrm{ng} \mathrm{m}^{-3}$ in winter) are very consistent with AZO observations (Table 3 ) and confirm the significance of biogenic sulfate in summer $\left(370 \mathrm{ng} \mathrm{m}^{-3}\right.$ compared to 270 ng $\mathrm{m}^{-3}$ measured at AZO, Table 3). Furthermore, it appears that the contribution of ship traffic $\left(420 \pm 180 \mathrm{ng} \mathrm{m}^{-3}\right)$ at this location is an important source of sulfate which exceeds those related to long-range transport from continents particularly in summer $\left(185 \pm 205 \mathrm{ng} \mathrm{m}^{-3}\right)$.

[55] The concentrations of $\mathrm{NH}_{4}^{+}$, another ion strongly influenced by anthropogenic activities, are strongly decreased from $1200 \mathrm{ng} \mathrm{m}^{-3}$ at AVE, to $105 \mathrm{ng} \mathrm{m}^{-3}$ at AZO (Figure 5). At continental sites $\mathrm{NH}_{4}^{+}$represents $\sim 10 \%$ of the (WSII + EC+ OM) mass (see Figures 3 and 5). At surface continental sites, in contrast to ammonium which exhibits rather similar levels in summer and winter, $\mathrm{NO}_{3}^{-}$ shows a strong winter maximum when low temperatures promote gas to particle conversion of semivolatile $\mathrm{NH}_{4} \mathrm{NO}_{3}$ aerosol.

\subsubsection{Other Ions}

[56] In addition to the preceding ions (sea-salt, non-seasalt and nondust sulfate, ammonium and nitrate) other ions contribute to a few percents of the (EC + OM + WSII) mass. They are present at larger levels at continental sites, particularly at the surface, than at AZO (Figure 5). They include cations not related to sea salt, and the mineral dust fraction of sulfate. A dominant fraction of these ions is related to mineral dust, except for potassium. Indeed, as seen in Figure 7, a large part of $\mathrm{K}^{+}$is present in the submicrometer sizes and thus cannot be attributed to mineral dust. Thought to be mainly related to wood burning [see Puxbaum et al., 2007] this fraction was estimated by subtracting first the sea-salt contribution, using the mass ratio of $\mathrm{K}^{+} / \mathrm{Na}^{+}$in seawater (0.038) and marine sodium levels. Since dust material contains leachable potassium we also have to consider this fraction to evaluate potassium related to wood burning. In contrast to the marine input, the amount of leachable potassium present in dust is variable. We therefore examined the relationship between $\mathrm{K}^{+}$and $\mathrm{Ca}^{2+}$ at continental sites in summer when input from sea salt and wood burning are expected to be minimal and dust input maximal. The slope of the lower envelope of the relationship observed between $\mathrm{K}^{+}$and $\mathrm{Ca}^{2+}$ in summer (not shown) is 0.16 at KPZ, 0.12 at SIL and 0.09 at PDD. On the basis of that, we corrected potassium from the dust contribution at all sites by using non-sea-salt calcium at AVE and AZO and total calcium at other sites, and assuming a mean $\mathrm{K}^{+} / \mathrm{Ca}^{2+}$ ratio of 0.12 . Note that this value is consistent with the ratio of $\mathrm{K}^{+}$to $\mathrm{Ca}^{2+}$ seen in coarse particles at KPZ (Figure 7). In spite of the crude estimate used in evaluating the potassium dust contribution, the correction does not exceed $35 \%$ of total potassium at continental sites (Table 2). Highest levels of nss-non-dust- $\mathrm{K}^{+}$are seen at surface continental sites in winter, where they represent a half of the part of other ions. In summer the other ions are dominated by $\mathrm{nss}_{-} \mathrm{Ca}^{2+}$ as result of a higher contribution of mineral dust at that season.

\subsection{Seasonal and Spatial Variability of OC and EC}

[57] The carbonaceous matter increases by a factor of 20 from the remote oceanic site of AZO to continental areas of AVE and KPZ, and intermediate levels are found at mountain sites (Figure 3).

[58] Except at AZO, there is a clear seasonal cycle of OC and EC at all sites. Carbonaceous matter is twice more abundant in winter than in summer at the low-level continental sites of AVE and KPZ (Table 4). Reversely OC and 
Table 4. Seasonal Means of the Levels of TC, EC and OC, the EC to OC Ratio, and the Contributions of OC1, OC2, OC3, and PC to OC, in Aerosol Collected at the Six CARBOSOL Sites

\begin{tabular}{|c|c|c|c|c|c|c|c|c|}
\hline Sites & $\mathrm{TC}, \mathrm{ngC} \mathrm{m}^{-3}$ & $\mathrm{EC}, \mathrm{ngC} \mathrm{\textrm {m } ^ { - 3 }}$ & $\mathrm{OC}, \mathrm{ngC} \mathrm{m}^{-3}$ & OC/EC, ng/ng & $\mathrm{OC} 1 / \mathrm{OC}, \%$ & $\mathrm{OC} 2 / \mathrm{OC}, \%$ & $\mathrm{OC} 3 / \mathrm{OC}, \%$ & $\mathrm{PC} / \mathrm{OC}, \%$ \\
\hline AZO S & 430 & 47 & 380 & 12.3 & 8 & 29 & 50 & 16 \\
\hline AZO W & 310 & 39 & 270 & 15.0 & 7 & 27 & 51 & 13 \\
\hline AVE S & 3700 & 650 & 3100 & 5.2 & 7 & 19 & 21 & 54 \\
\hline AVE W & 8800 & 1340 & 7500 & 5.6 & 8 & 19 & 20 & 53 \\
\hline PDD S & 2600 & 260 & 2400 & 10.6 & 5 & 21 & 21 & 52 \\
\hline PDD W & 970 & 185 & 790 & 5.6 & 6 & 24 & 26 & 45 \\
\hline SIL S & 3700 & 350 & 3400 & 11.1 & 7 & 21 & 20 & 51 \\
\hline SIL W & 1590 & 220 & 1370 & 6.4 & 5 & 19 & 24 & 53 \\
\hline SBO $\mathrm{S}$ & 1610 & 230 & 1380 & 7.9 & 5 & 28 & 36 & 31 \\
\hline SBO $\mathrm{W}$ & 550 & 66 & 480 & 11.2 & 9 & 26 & 38 & 30 \\
\hline KPZ S & 5600 & 690 & 4900 & 8.0 & 3 & 20 & 26 & 51 \\
\hline KPZ W & 8900 & 1570 & 7400 & 4.9 & 7 & 17 & 19 & 57 \\
\hline
\end{tabular}

EC levels are 2 to 3 times higher during summer than winter at mountain sites. This different seasonal cycle between surface and mountain sites reflects the different transport and dispersion of emissions. As already learned from radioisotopes (section 4.1), higher levels in winter at AVE and $\mathrm{KPZ}$ are presumably related to higher emissions at local level with much more limited dispersion during these cold months. The high carbonaceous aerosol levels in summer at the mountain sites partly reflect the efficient upward transport from the polluted boundary layer during summer, as clearly indicated by the ${ }^{210} \mathrm{~Pb}$ seasonality (Table 1 ).

[59] There are some differences in the relative abundance of OC and EC from site to site. That may result from the different size cutoffs used in the CARBOSOL campaign; being OC more distributed in larger particle than EC. This would lead to a somehow higher OC/EC ratio at PDD and SIL than at the other sites, only as result of sampling methodology. While at AZO and AVE the OC/EC ratio does not change significantly from winter to summer, there is a relative enrichment in $\mathrm{OC}$ with respect to $\mathrm{EC}$ in summer at KPZ, PDD and SIL (Table 4). At all sites the OC/EC ratio is much higher than the values considered previously, using a similar analytical technique, for primary emissions of OC (primary OC/EC = 1.1) [Castro et al., 1999; Carvalho et al., 2006]. The ratio of 1.1 was derived from minimum observed during winter at Portuguese and British urban sites. OC present in excess, with respect to this ratio, was considered by Castro et al. [1999] as having a secondary origin from gas-particle conversion. This assumption is based on the idea that only direct emissions of OC and EC from cars and other urban primary sources were present in the atmosphere and that during transport from urban areas, gas-particle conversion of VOCs happened, adding secondary $\mathrm{OC}$ to the primary aerosol. If this approach was applied to our data the percentage of secondary OC would be, at all sites, $62 \%$ to $81 \%$ in winter, and $74 \%$ to $86 \%$ in summer. At AVE, surprisingly there are higher percentages of secondary $\mathrm{OC}$ in winter than in summer. A possible explanation is the existence of primary emissions of carbonaceous aerosols containing a higher OC/EC ratio. Several studies [Cachier et al., 1989; Castro, 1997; Cabada et al., 2002; Park et al., 2003; Cao et al., 2005; Yang et al., 2005] have shown that biomass burning usually leads to higher OC/EC emission ratios. Direct emissions from wood burning during winter for home heating are then a good reason to explain the high $\mathrm{OC} / \mathrm{EC}$ values seen in winter at AVE. In
Azores the high OC/EC values may result of secondary production from gas to particle conversion of VOCs during long-range transport of polluted air masses from continental areas, or be related to direct emission of hydrophobic organic compounds, accumulated on the ocean surface layer, with sea spray [O'Dowd et al., 2004].

[60] In the CARBOSOL project, the study of several tracers of primary emissions, such as levoglucosan and cellulose, and of biogenic recent formation such as ${ }^{14} \mathrm{C}$, permitted to estimate accurately the origins of the carbonaceous atmospheric aerosol. Using this tracer data and a methodology detailed in section 4.6 of this paper, Gelencsér et al. [2007] calculated the secondary formation of OC in a subset of summer and winter pooled samples at the five continental CARBOSOL sites. Application of the OC/EC factor of 1.1 to the same summer and winter subset of samples used by Gelencsér et al. [2007], leads to an important overestimation of secondary OC in winter samples at low land sites of AVE and KPZ, because of the interference effect of biomass burning emissions. However, the results are quite similar between both methodologies at all sites during summer, suggesting that the simple use of $\mathrm{OC} / \mathrm{EC}$ factor of 1.1 to estimate secondary carbon aerosol formation in rural and remote European areas, in summer conditions, is adequate. The results are also rather similar in winter high-altitude sites located away from fresh residential biomass burning emissions. This may be due to a more rapid removal of hydrophilic biomass burning carbon emissions by clouds and rain, resulting in a relative enrichment in the free troposphere of more hydrophobic fossil fuel burning particulate emissions.

[61] The nature of particulate organic matter can be evaluated from the inspection of the carbon mass thermal evolution during analysis. Table 4 shows that at all sites the OC1 (the OC fraction evaporated at temperatures up to $150^{\circ} \mathrm{C}$ ) represents 5 to $9 \%$ of $\mathrm{OC}$, indicating a weak contribution of semivolatile organic species to the carbonaceous aerosol load (although some semivolatile OC may have been charred during the heating process). This finding likely suggests that no significant absorption occurred on aerosol filters during sampling. During the analysis most of $\mathrm{OC}$ evolves at temperatures above $350^{\circ} \mathrm{C}$ (Table 4). At the most remote sites of AZO and SBO the largest fraction of $\mathrm{OC}$ comes out as OC3, whereas at all other locations more than $50 \%$ of OC results from charring during analysis. 
Table 5. Seasonal Variations of Organic Carbon, Water Soluble Organic Carbon (WSOC), HULIS, Sum of Dicarboxylic Acids, Total Cellulose and Levoglucosan, at the Six CARBOSOL Sites ${ }^{\mathrm{a}}$

\begin{tabular}{lcccccc}
\hline Sites & $\mathrm{OC}, \mathrm{ngC} \mathrm{m}^{-3}$ & $\begin{array}{c}\text { WSOC, } \\
\mathrm{ngC} \mathrm{m}^{-3}\end{array}$ & $\begin{array}{c}\text { HULIS, } \\
\mathrm{ngC} \mathrm{m}^{-3}\end{array}$ & $\begin{array}{c}\text { Diacids, } \\
\mathrm{ngC} \mathrm{m}^{-3}\end{array}$ & $\begin{array}{c}\text { Total Cellulose, } \\
\mathrm{ngC} \mathrm{m}^{-3}\end{array}$ & $\begin{array}{c}\text { Levoglucosan, } \\
\mathrm{ngC} \mathrm{m}^{-3}\end{array}$ \\
\hline AZO S & 380 & 211 & 105 & 28 & 9 & 1 \\
AZO W & 270 & 181 & 87 & 12 & 6 & 4 \\
AVE S & 3100 & 1800 & 940 & 109 & 23 & 34 \\
AVE W & 7500 & 3700 & 2900 & 94 & 41 & 5 \\
PDD S & 2400 & 1540 & 480 & 93 & 50 & 10 \\
PDD W & 790 & 610 & 370 & 34 & 16 & 8 \\
SIL S & 3400 & 2700 & 680 & 159 & 84 & 2 \\
SIL W & 1370 & 1020 & 570 & 51 & 27 & 4 \\
SBO S & 1380 & 840 & 360 & 49 & 24 & 29 \\
SBO W & 480 & 350 & 179 & nd & 15 & 260 \\
KPZ S & 4900 & 3400 & 950 & 111 & 107 & 26 \\
KPZ W & 7400 & 5800 & 4400 & 123 & & 66 \\
\hline
\end{tabular}

${ }^{\mathrm{a}}$ nd, not determined.

[62] Given the weekly sampling period, it may be questioned if either species existed already in the atmosphere in an oxidized state or if the oxidation occurred on filter during sampling. Of course both processes may happen but the fact that the fraction of PC does not change significantly from summer to winter and is much lower at remote than at more polluted sites (Table 4) suggests that aerosol already exists in the atmosphere in an oxidized form. The existence of high percentages of $\mathrm{PC}$ at most polluted rural areas and the absence of decreasing PC levels during colder months indicates that photochemical processes acting on VOCs or particulate organics, are not the only responsible for the presence of polar organic matter in the aerosol. If these processes were predominant, the fractional amount of PC would be higher in summer than in winter at all sites and also higher at more remote sites where aerosol have been long-range transported, having a longer time to become more oxidized. The much lower relative contribution of PC in aerosol at Azores indicates different characteristics and origin of the organic matter at this oceanic remote site. The higher PC levels and constant PC fraction during winter in less remote continental sites are a strong indication of the primary origin of an important part of the polar oxygenated organic aerosol mass.

\subsection{Water Soluble Organic Carbon}

[63] As seen in Table 5, a large fraction of OC is water soluble at all sites. WSOC contains the more oxygenated and polar fraction of particulate organic carbon. The WSOC includes numerous classes of polar species, from sugars, alcohols, acids and aldehydes, to macromolecular species referred as Humic Like Substances (HULIS) [Decesari et al., 2001]. At Aveiro, the WSOC extracts were analyzed for elemental composition and average atomic ratios for $\mathrm{C}: \mathrm{H}: \mathrm{O}: \mathrm{N}$ of 16:22:9:1 and 30:39:13:1 are calculated for summer and winter, respectively [Duarte, 2006]. From that it can be concluded that the WSOC is highly oxidized, especially in summer, and contains an important number of nitrogen associated groups.

[64] Usually it is assumed that WSOC represents organic compounds that result from the atmospheric oxidation of VOCs and gas-particle conversion (secondary OC). Oxygenation of particulate $\mathrm{OC}$ may also happen in the particulate phase (in the atmosphere or on filters during sampling) by reaction of strong oxidants such as ozone or peroxide radicals
[Gelencsér, 2004]. As a result of these processes the fraction of WSOC in OC is usually minimum in urban locations near fossil fuel sources $(\sim 20 \%)$ and increases at more remote locations during aging of aerosol [Ruellan and Cachier, 2001; Carvalho, 2003; Pöschl, 2005; Yu et al., 2005].

[65] Information on organic aerosol with regard to its water solubility is sparse in Europe. As far as we know, our data are the most extensively available for nonurban sites in Europe. They show that, at all sites, most of organic carbon is water soluble (from $50 \%$ to $80 \%$ of OC, see Table 5), the lowest values being seen at coastal sites. These values are in agreement with other studies carried out at background and rural sites in Europe. Zappoli et al. [1999] observed WSOC fractions of $52-83 \%$ of OC at three nonurban sites (including KPZ) in Europe. Krivácsy et al. [2001] measured values of 40, 60 and $65 \%$ in PM2.5 aerosol samples collected during summer at Mace Head (Ireland, coastal background), Jungfraujoch, (Switzerland, background, mountain), and K-Puszta, respectively. Fractions of WSOC of the order of 12 to $49 \%$ of OC were found in PM10 at urban areas in Portugal, Spain and UK and of $39 \%$ on a Finnish forest during summer [Carvalho, 2003]. One year of measurements performed by Carvalho [2003] in Azores revealed an average WSOC contribution of $36 \%$ to OC, for submicrometer aerosol, and $29 \%$ to OC in supermicrometer particles $(1-10 \mu \mathrm{m})$.

[66] The levels of WSOC follow the seasonal change of OC at CARBOSOL sites and there is no clear seasonal variability in the fraction of $\mathrm{OC}$ that is water soluble. WSOC concentrations are higher in summer for remote marine and mountain sites and higher in winter for surface AVE and KPZ sites (Table 5). This leads to possible different origins of WSOC depending of the season, with summer values probably resulting from photochemical oxidation processes and winter values resulting from direct emissions of oxygenated particulate organics from sources such as biomass burning (see Puxbaum et al. [2007], and Gelencsér et al. [2007], to confirm the strong contribution of biomass burning to the carbonaceous aerosol in winter).

[67] Complete identification and quantification of individual organic species is impossible since an important fraction of OM has a chemical signature similar to humic species. In spite of their abundance in the atmosphere, the origin of these macromolecules is not yet well understood (see further discussions by Lukács et al. [2007]) but we 
emphasize here their important contribution to WSOC. Although the mass concentrations of HULIS cannot be used easily into mass closure calculations [Lukács et al., 2007] Table 5 permits to conclude that carbon associated with HULIS constitute a large fraction of WSOC at all sites, particularly in winter at continental sites (possible as high as $80 \%$ at AVE, SBO and KPZ). This finding is important for the climate, given the light-absorbing properties of HULIS. The dominant presence of HULIS in winter aerosol in Europe will be discussed in details by Lukács et al. [2007] and strongly points out the role of wood burning.

\subsection{Complementary Information Found in Companion Papers in This Issue}

[68] In addition to the preceding climatology of major fractions of aerosol in Europe (inorganic versus organic, EC versus OC, WSOC versus OC) additional discussions on sources of more specific organic species were made during the CARBOSOL project.

[69] As already mentioned the large presence of HULIS observed in the European atmosphere may resolve a large fraction of unexplained mass of OM in the atmosphere. The ultimate origin of this compound class has not been identified yet. Although biomass burning is a probable primary source [Zappoli et al., 1999; Mayol-Bracero et al., 2002], most recent studies line up strong experimental evidence for their secondary formation, too [Graber and Rudich, 2006]. The CARBOSOL climatology of HULIS is evaluated in view to their possible source apportionment in two companion papers [Lukács et al., 2007; Feczko et al., 2007]. The spatiotemporal variation of HULIS together with other aerosol constituents like levoglucosan, in combination with investigations of the size distribution helped to test the hypotheses proposed for HULIS formation.

[70] Better defined than HULIS are $\mathrm{C}_{2}-\mathrm{C}_{5}$ dicarboxylic acids (oxalic, malonic, succinic, malic, tartaric, and glutaric) that are still significant contributors to WSOC (from 3 to $7 \%$ at continental sites and up to $14 \%$ at $\mathrm{AZO}$ in summer, Table 5). The climatology of $\mathrm{C}_{2}-\mathrm{C}_{5}$ dicarboxylic acids in Europe is discussed by Legrand et al. [2007] versus environmental conditions at sites (marine versus continental, rural versus forested, boundary layer versus free troposphere, winter versus summer). Continental surface sites seem in winter to be influenced by primary $\mathrm{C} 2-\mathrm{C} 5$ emissions from regional vehicular traffic and wood burning plumes, and secondary aqueous production of C2 from aldehydes formed by the rapid oxidation of toluene and ethene emitted by cars. In summer, these polluted plumes are more efficiently dispersed from the boundary layer and emissions from larger scale become important. It is shown that they include successive aqueous decarboxylations of glutaric acid formed by terpene oxidation and aqueous production of $\mathrm{C} 2$ from aldehydes formed by oxidation of isoprene. Finally diacids present at the Azores are not only related to long-range transport from continents but also to in situ productions from precursors emitted by the marine biosphere (particulate unsaturated fatty acids and ethene) in summer.

[71] Levoglucosan has been previously shown to be associated with burning of biomass, being emitted predominantly by combustion of wood as result of thermal breakdown of cellulose at high temperatures [Fraser and
Lakshmanan, 2000]. Stable in the atmosphere for more than 10 days it is thus a good candidate to trace back contribution of biomass burning to the atmospheric organic aerosol load. Using the climatology of levoglucosan and other potential tracers of wood burning (nss-ndust- $\mathrm{K}^{+}$, for instance) specific treatment and calculation of biomass burning contribution to the carbonaceous aerosol is presented in another paper [Puxbaum et al., 2007]. It is shown that, surprisingly, high relative concentrations of biomass smoke in OM $(20-68 \%)$ were observed for winter conditions at all CARBOSOL sites.

[72] As seen in Table 5, cellulose, an organic aerosol component introduced in the atmosphere as a result of resuspension of plant debris, is present at a few tens of $\mathrm{ngC} \mathrm{m} \mathrm{m}^{-3}$ and represents a significant fraction of WinOC. Detailed evaluation of cellulose climatology and production processes is given in another paper [Sánchez-Ochoa et al., 2007]. Since cellulose (and related material) is considered rather long-lived with respect to atmospheric oxidation processes, it may become enriched on the route to background regions, which may explain the observed higher relative levels at mountain sites compared to the lowland sites.

[73] The organic aerosol is composed by an enormous amount of compounds that it is not yet possible to identify and quantify totally with the existing analytical techniques. The most common analytical methods involve extraction with solvents and measurements with GC/MS. Pooled samples representing monthly average conditions during 1 year of CARBOSOL sampling were extracted with dichloromethane and analyzed for tracer organic compounds by GC/MS. More than 200 compounds were identified and quantified, including 24 alkanes, 33 polyaromatic hydrocarbons, 23 aldehydes, 27 ketones, 23 alcohols, and 50 organic acids. Specific discussion and interpretation of GC/MS results are given by Oliveira et al. [2007]. Here we only emphasize that the identified and quantified organic species represent only from $2 \%$ to $4 \%$ of OM.

[74] Finally, on the basis of the 2-year comprehensive data set here obtained, seasonal source apportionment of PM2.5 aerosol was attempted for the CARBOSOL sites [Gelencsér et al., 2007]. The methodology combines radiocarbon measurements with bulk measurements of OC, EC, levoglucosan and cellulose and emission factors for fossil fuel burning in road tunnels and in domestic biomass burning. The approach was to lump source types of (EC + OC) into primary emissions from fossil fuel combustion and biomass burning, primary bioaerosol, and secondary organic aerosol from precursors emitted by fossil and nonfossil-fuel sources. It is found that while fossil-related EC predominates throughout the year at all sites, the sources of OC are primarily non-fossil-fuel and markedly differ from summer to winter. In winter biomass burning primary emission is the main source whereas in summer secondary production from non-fossil-fuel precursors becomes predominant.

\section{Conclusions}

[75] Present-day climatology of aerosol acquired during CARBOSOL shows that, except at the Azores where 
inorganic material dominates, similar amounts of organic and inorganic matter are found in the nonurban European atmosphere. This extensive data set for nonurban environment also permits characterization of $\mathrm{OC}$ aerosol with regard to water solubility, showing that most $(50-80 \%)$ of OC is water-soluble. CARBOSOL results suggest that, in addition to sulfate, OC has to be considered, as well, in discussing the role of clouds on climate over Europe. During summer a large fraction of OC is found to be secondary. However, in winter, principally at lowland sites, quite substantial amounts of organic matter seem to have a primary origin in biomass burning.

[76] Acknowledgments. This work was financed by European Commission through the Project CARBOSOL (EVK2-2001-113). We are grateful for the logistical support by the Federal German Environmental Agency and for the invaluable help by the staff of the Schauinsland station concerning filter samplings. We also gracefully acknowledge the Portuguese Foundation for Science and Technology, for the scholarship given to T. Oliveira and for financial support through the Research Unit CESAM (Centre for Environmental and Marine Studies).

\section{References}

Alves, C., A. Carvalho, and C. Pio (2002), Mass balance of organic carbon fractions in atmospheric aerosols, J. Geophys. Res., 107(D21), 8345, doi:10.1029/2001JD000616.

Andreae, M. O., C. D. Jones, and P. M. Cox (2005), Strong present-day aerosol cooling implies a hot future, Nature, 435, 1187-1190.

Bates, S. T., J. A. Calhoun, and P. K. Quinn (1992), Variations in the methanesulfonate to sulfate molar ratio in submicrometer marine aerosol particles over the South Pacific ocean, J. Geophys. Res., 97, 9859-9865.

Bellouin, N., O. Boucher, J. Haywood, and M. S. Reddy (2005), Global estimate of aerosol direct radiative forcing from satellite measurements, Nature, 438, 1138-1141.

Boucher, O., et al. (1998), Intercomparison of models representing direct shortwave radiative forcing by sulfate aerosols, J. Geophys. Res., 103, 16,979-16,998

Cabada, J., S. Pandis, and A. Robinson (2002), Sources of atmospheric carbonaceous particulate matter in Pittsburgh, Pennsylvania, J. Air Waste Manage., 52, 732-741.

Cachier, H., M. P. Bremond, and P. Buat-Ménard (1989), Carbonaceous aerosols from different tropical biomass burning sources, Nature, 340, $371-373$.

Camacho-García, A. (2000), Factores condicionantes de la radiactividad medioambiental en áreas del S. E., Peninsular, Ph.D. thesis, Univ. of Granada, Granada, Spain.

Cao, J. J., J. C. Chow, S. C. Lee, Y. Li, S. W. Chen, Z. S. An, K. Fung, J. G. Watson, C. S. Zhu, and S. X. Liu (2005), Characterization and source apportionment of atmospheric organic and elemental carbon during fall and winter of 2003 in Xi'an, China, Atmos. Chem. Phys. Disc., 5, $3561-$ 3593.

Carvalho, A. (2003), Characterization of atmospheric carbonaceous aerosols: Secondary and water soluble compounds, Ph.D. thesis, Univ. of Aveiro, Aveiro, Portugal.

Carvalho, A., C. Pio, C. Santos, and C. Alves (2006), Particulate carbon in the atmosphere of a Finnish forest and a German anthropogenically influenced grassland, Atmos. Res., 80, 133-150.

Castro, L. M. (1997), Composition and origin of particulate pollutants in a coastal atmosphere, Ph.D. thesis, Univ. of Aveiro, Aveiro, Portugal.

Castro, L., C. Pio, R. Harrison, and D. Smith (1999), Carbonaceous aerosol in urban and rural European atmospheres: Estimation of secondary organic carbon concentrations, Atmos. Environ., 33, 2771-2781.

Charlson, R. J., S. E. Schwartz, J. M. Hales, R. D. Cess, J. A. Coakley Jr., J. E. Hansen, and D. J. Hofmann (1992), Climate forcing by anthropogenic aerosols, Science, 255, 423-430.

Chow, J., J. Watson, D. Crow, D. Lowenthal, and T. Merrifield (2001), Comparison of IMPROVE and NIOSH carbon measurements, Aerosol Sci. Technol., 34, 23-34.

Decesari, S., M. C. Facchini, E. Matta, F. Lettini, M. Mircea, S. Fuzzi, E. Tagliavini, and J.-P. Putaud (2001), Chemical features and seasonal variation of fine aerosol water-soluble organic compounds in the Po Valley, Italy, Atmos. Environ., 35, 3691-3699.

Duarte, R. M. (2006), Mass balance and characterization of organic matter in atmospheric aerosols, Ph.D. thesis, Univ. of Aveiro, Aveiro, Portugal.
Dueñas, C., M. C. Fernández, J. Carretero, E. Liger, and S. Cañete (2005), Deposition velocities and washout ratios on a coastal site (southeastern Spain) calculated from ${ }^{7} \mathrm{Be}$ and ${ }^{210} \mathrm{~Pb}$ measurements, Atmos. Environ., 39, 6897-6908.

Feczko, T., H. Puxbaum, A. Kasper-Giebl, M. Handler, A. Limbeck, A. Gelencsér, C. Pio, S. Preunkert, and M. Legrand (2007), Determination of water and alkaline extractable atmospheric humic-like substances with the TU Vienna HULIS-analyser in samples from six background sites in Europe, J. Geophys. Res., doi:10.1029/2006JD008331, in press.

Fraser, M. P., and K. Lakshmanan (2000), Using levoglucosan as a molecular marker for the long-range transport of biomass combustion aerosols, Environ. Sci. Technol., 34, 4560-4564.

Gelencsér, A. (2004), Carbonaceous Aerosol, Ser. Atmos. and Oceanogr. Sci. Libr, vol. 30, 350 pp., Springer, New York.

Gelencsér, A., B. May, D. Simpson, A. Sánchez-Ochoa, A. Kasper-Giebl, H. Puxbaum, C. Pio, and M. Legrand (2007), Source apportionment of PM2.5 organic aerosol over Europe: Primary/secondary, natural/anthropogenic, and fossil/biogenic origin, J. Geophys. Res., doi:10.1029/ 2006JD008094, in press.

Graber, E. R., and Y. Rudich (2006), Atmospheric HULIS: How humic-like are they? A comprehensive and critical review, Atmos. Chem. Phys., 6, $729-753$.

Hammer, S., D. Wagenbach, S. Preunkert, C. Pio, and F. Meinhardt (2007), Observations of ${ }^{210} \mathrm{~Pb}$ within CARBOSOL: A diagnostic tool for assessing the spatiotemporal variability of related chemical aerosol species?, J. Geophys. Res., doi:10.1029/2006JD008065, in press.

Harrison, R. M., A. M. Jones, and R. G. Lawrence (2003), A pragmatic mass closure model for airborne particulate matter at urban background and roadside sites, Atmos. Environ., 37, 4927-4933.

Heintzenberg, J. (1989), Fine particles in the global troposphere, a review, Tellus, Ser. B, 41, 149-160.

Honrath, R. E., R. C. Owen, M. Val Martýn, J. S. Reid, K. Lapina, P. Fialho, M. P. Dziobak, J. Kleissl, and D. L. Westphal (2004), Regional and hemispheric impacts of anthropogenic and biomass burning emissions on summertime $\mathrm{CO}$ and $\mathrm{O}_{3}$ in the North Atlantic lower free troposphere, J. Geophys. Res., 109, D24310, doi:10.1029/2004JD005147.

Hughes, L. S., G. R. Cass, J. Gone, M. Ames, and I. Lomez (1998), Physical and chemical characterisation of atmospheric ultrafine particles in the Los Angeles area, Environ. Sci. Technol., 32, 1153-1161.

Huntzicker, J., R. Johnson, J. Shah, and R. Cary (1982), Analysis of organic and elemental carbon in ambient aerosols by a thermal-optical method, in Particulate Carbon: Atmospheric Lyfe Cycle, edited by D. Wolff and R. Klimisch, pp. 79-88, Plenum, New York.

Jacobson, M. Z. (2001), Strong radiative heating due to the mixing state of black carbon in atmospheric aerosols, Nature, 409, 695-697.

Kasper, A., and H. Puxbaum (1998), Seasonal variation of $\mathrm{SO}_{2}, \mathrm{HNO}_{3}$, $\mathrm{NH}_{3}$ and selected aerosol components at Sonnblick (3106 m a.s.1.), Atmos. Environ., 32, 3925-3939.

Kawamura, K., and K. Usukura (1993), Distributions of low molecular weight dicarboxylic acids in the north Pacific aerosol samples, J. Oceanogr., 49, $271-283$.

Krivácsy, Z., A. Hoffer, T. Sárvári, D. Temesi, U. Baltensperger, S. Nyeki, E. Weingartner, S. Kleefeld, and S. G. Jennings (2001), Role of organic and black carbon in the chemical composition of atmospheric aerosols at European background sites, Atmos. Environ., 35, 6231-6244.

Lefohn, A., J. Husar, and R. Husar (1999), Estimating historical anthropogenic global sulphur emission patterns for the period 1850-1990, Atmos. Environ., 33, 3435-3444.

Legrand, M., and H. Puxbaum (2007), Introduction of the CARBOSOL project: Present and Retrospective State of Organic versus Inorganic Aerosol over Europe, J. Geophys. Res., doi:10.1029/2006JD008271, in press.

Legrand, M., S. Preunkert, D. Wagenbach, and H. Fischer (2002), Seasonally resolved Alpine and Greenland ice core records of anthropogenic $\mathrm{HCl}$ emissions over the 20th century, J. Geophys. Res., 107(D12), 4139, doi:10.1029/2001JD001165.

Legrand, M., S. Preunkert, T. Oliveira, C. Pio, S. Hammer, A. Gelencsér, A. Kasper-Giebl, and P. Laj (2007), Origin of C2-C5 dicarboxylic acids in the European atmosphere inferred from year-round aerosol study conducted at a west-east transect, J. Geophys. Res., doi:10.1029/ 2006JD008019, in press.

Limbeck, A., M. Handler, B. Neuberger, B. Klatzer, and H. Puxbaum (2005), Carbon-specific analysis of humic-like substances in atmospheric aerosol and precipitation samples, Anal. Chem., 77, 7288-7293, doi:10.1021/ac0509531.

Lohmann, U., J. Feichter, J. Penner, and R. Leaitch (2000), Indirect effect of sulfate and carbonaceous aerosols: A mechanistic treatment, J. Geophys. Res., 105, 12,193-12,206.

Lukács, H., A. Gelencsér, H. Puxbaum, C. Pio, M. Legrand, A. Caseiro, A. Limbeck, and S. Preunkert (2007), Seasonal trends and possible sources 
of brown carbon based on two-year aerosol measurements at six sites in Europe, J. Geophys. Res., doi:10.1029/2006JD008151, in press.

Mason, B., and C. B. Moore (1984), Principles of Geochemistry, John Wiley, Hoboken, N. J.

Mayol-Bracero, O. L., P. Guyon, B. Graham, G. Roberts, M. O. Andreae, S. Decesari, M. C. Facchini, S. Fuzzi, and P. Artaxo (2002), Water-soluble organic compounds in biomass burning aerosols over Amazonia: 2. Apportionment of the chemical composition and importance of the polyacidic fraction, J. Geophys. Res., 107(D20), 8091, doi:10.1029/ 2001JD000522.

Menon, S. (2004), Current uncertainties in assessing aerosol effects on climate, Annu. Rev. Environ. Resour., 29, 1-30.

O’Dowd, C., M. C. Facchini, F. Cavalli, D. Ceburnis, M. Mircea, S. Decesari, S. Fuzzi, Y. J. Yoon, and J.-P. Putaud (2004), Biogenically driven organic contribution to marine aerosol, Nature, 431, 676-680.

Oliveira, T. S., C. A. Pio, C. A. Alves, A. J. D. Silvestre, M. Evtyugina, J. V. Afonso, P. Fialho, M. Legrand, H. Puxbaum, and A. Gelencser (2007), Seasonal variation of particulate lipophilic organic compounds at nonurban sites in Europe, J. Geophys. Res., doi:10.1029/2007JD008504, in press.

Park, R. J., D. J. Jacob, M. Chin, and R. V. Martin (2003), Sources of carbonaceous aerosols over the United States and implications for natural visibility, J. Geophys. Res., 108(D12), 4355, doi:10.1029/ 2002JD003190.

Penner, J. E., R. J. Charlson, J. M. Hales, N. Laulainen, R. Leifer, T. Novakov, J. A. Ogren, L. F. Radke, S. E. Schwartz, and L. Travis (1994), Quantifying and minimizing uncertainty of climate forcing by anthropogenic aerosols, Bull. Am. Meteorol. Soc., 75, 375-400.

Penner, J. E., C. C. Chuang, and K. Grant (1998), Climate forcing by carbonaceous and sulfate aerosols, Clim. Dyn., 14, 839-851.

Pio, C., L. Castro, and M. Ramos (1994), Differentiated determination of organic and elemental carbon in atmospheric aerosol particles by a thermal-optical method, in Proceedings of the Sixth European Symposium on Physico-Chemical Behaviour of Atmospheric Pollutants, edited by G. Angeletti and G. Restelli, Rep. EUR 15609/2 EN, pp. 706-711, Dir. Gen. for Sci., Res., and Dev., Eur. Comm., Brussels.

Pio, C., C. Alves, and A. Duarte (2001), Identification, abundance and origin of atmospheric particulate matter in a Portuguese rural area, Atmos. Environ., 35, 1365-1375.

Pope, C. A. (2000), Review: Epidemiological basis for particulate air pollution health standards, Aerosol Sci. Technol., 32, 4-14.

Pöschl, U. (2005), Atmospheric aerosols: Composition, transformation, climate and health effects, Angew. Chem. Int. Ed., 44, 7520-7540.

Putaud, J.-P., et al. (2004), A European aerosol phenomenology-2: Chemical characteristics of particulate matter at kerbside, urban, rural and background sites in Europe, Atmos. Environ., 38, 2579-2595.

Puxbaum, H., and M. Tenze-Kunit (2003), Size distribution and seasonal variation of atmospheric cellulose, Atmos. Environ., 37, 3693-3699.

Puxbaum, H., A. Caseiro, A. Sánchez-Ochoa, A. Kasper-Giebl, M. Claeys, A. Gelencsér, M. Legrand, S. Preunkert, and C. A. Pio (2007), Levoglucosan levels at background sites in Europe for assessing the impact of biomass combustion on the European aerosol background, J. Geophys. Res., doi:10.1029/2006JD008114, in press.

Ricard, V., J.-L. Jaffrezo, V.-M. Kerminen, R. E. Hillamo, M. Sillanpaa, S. Ruellan, C. Liousse, and H. Cachier (2002), Two years of continuous aerosol measurements in northern Finland, J. Geophys. Res., 107(D11), 4129, doi:10.1029/2001JD000952.

Ruellan, S., and H. Cachier (2001), Characterization of fresh particulate vehicular exhaust near a Paris high flow road, Atmos. Environ., 35, 453468.

Sánchez-Ochoa, A., A. Kasper-Giebl, H. Puxbaum, A. Gelencsér, M. Legrand, and C. A. Pio (2007), Concentration of atmospheric cellulose: A proxy for plant debris across a west-east transect over Europe, J. Geophys. Res., 112, D23S08, doi:10.1029/2006JD008180.
Saxena, P., L. M. Hildeman, P. H. McMurry, and J. H. Seinfeld (1995), Organics alter hygroscopic behavior of atmospheric particles, J. Geophys. Res., 100(D9), 18,755-18,770.

Schmid, H., et al. (2001), Results of the "carbon conference" international aerosol carbon round robin test stage I, Atmos. Environ., 35, 2111-2121. Sellegri, K., P. Laj, F. Peron, R. Dupuy, M. Legrand, S. Preunkert, J.-P. Putaud, H. Cachier, and G. Ghermandi (2003), Mass balance of free tropospheric aerosol at the Puy de Dôme (France) in winter, J. Geophys. Res., 108(D11), 4333, doi:10.1029/2002JD002747.

Sempéré, R., and K. Kawamura (2003), Trans-hemispheric contribution of $\mathrm{C}_{2}-\mathrm{C}_{10} \alpha$, $\omega$-dicarboxylic acids, and related polar compounds to watersoluble organic carbon in the western Pacific aerosols in relation to photochemical oxidation reactions, Global Biogeochem. Cycles, 17(2), 1069, doi:10.1029/2002GB001980.

Simoneit, B. R. T., and M. A. Mazurek (1982), Organic matter of the troposphere-II, Natural background of biogenic lipid matter in aerosols over the rural western United States, Atmos. Environ., 16, 2139-2159.

Turpin, B. J., and H.-J. Lim (2001), Species contributions to PM2.5 mass concentrations: Revisiting common assumptions for estimating organic mass, Aerosol Sci. Technol., 35, 602-610.

Turpin, B. J., P. Saxena, and E. Andrews (2000), Measuring particulate organics in the atmosphere: Problems and prospects, Atmos. Environ., 34, 2983-3013.

van Aardenne, J., F. Dentener, J. Olivier, C. Goldewijk, and J. Lelieveld (2001), A $1^{\circ} \times 1^{\circ}$ resolution data set of historical anthropogenic trace gas emissions for the period 1890-1990, Global Biogeochem. Cycles, 15, 909-928.

Van Dingenen, R., et al. (2004), A European aerosol phenomenology-1: Physical characteristics of particulate matter at kerbside, urban, rural and background sites in Europe, Atmos. Environ., 38, 2561-2577.

Varga, B., G. Kiss, I. Ganszky, A. Gelencsér, and Z. Krivacsy (2001), Isolation of water-soluble organic matter from atmospheric aerosol, Talanta, 55, 561-572.

Wagenbach, D., U. Görlach, K. Moser, and K. O. Münnich (1988), Coastal Antarctic aerosol: the seasonal pattern of its chemical composition and radionuclide content, Tellus, Ser. B, 40, 426-436.

Yang, F., K. He, B. Ye, X. Chen, L. Cha, S. H. Cadle, T. Chan, and P. A. Mulawa (2005), One-year record of organic and elemental carbon in fine particles in downtown Beijing and Shanghai, Atmos. Chem. Phys. Disc., 5, 217-241.

Yu, L. E., M. L. Shulman, R. Kopperud, and L. M. Hildemann (2005), Fine organic aerosols collected in humid, rural location (Great Smoky Mountains, Tennessee, USA): Chemical and temporal characteristics, Atmos. Environ., 39, 6037-6050.

Zappoli, S., et al. (1999), Inorganic, organic and macromolecular components of fine aerosol in different areas of Europe in relation to their water solubility, Atmos. Environ., 33, 2733-2743.

J. Afonso, A. Caseiro, T. Oliveira, C. A. Pio, and C. Santos, Centre for Environmental and Marine Studies and Department of Environment, University of Aveiro, 3810-193 Aveiro, Portugal. (casimiro@ua.pt)

F. Barata and P. Fialho, Department of Agrarian Sciences, University of the Azores, Terra Chã, Angra do Heroísmo 9701-851, Portugal.

A. Gelencsér, Air Chemistry Group at the Hungarian Academy of Sciences, University of Pannonia, Egyetem u. 10, 8200 Veszprém, Hungary.

A. Kasper-Giebl, H. Puxbaum, and A. Sanchez-Ochoa, Institute for Chemical Technologies and Analytics, Vienna University of Technology, A-1040 Vienna, Austria.

M. Legrand and S. Preunkert, Laboratoire de Glaciologie et Géophysique de l'Environnement, Centre National de la Recherche Scientifique, F-38402 Saint Martin d'Héres, France.

M. Schock, Institut für Umweltphysik, Universität Heidelberg, D-60120 Heidelberg, Germany. 